Columbia Law School

Scholarship Archive

1981

\title{
"Twisting Slowly in the Wind": A Search for Constitutional Limits on Coercion of the Criminal Defendant
}

John C. Coffee Jr.

Columbia Law School, jcoffee@law.columbia.edu

Follow this and additional works at: https://scholarship.law.columbia.edu/faculty_scholarship

Part of the Constitutional Law Commons, and the Criminal Law Commons

\section{Recommended Citation}

John C. Coffee Jr., "Twisting Slowly in the Wind": A Search for Constitutional Limits on Coercion of the Criminal Defendant, 1980 Sup. Ст. Rev. 211 (1981).

Available at: https://scholarship.law.columbia.edu/faculty_scholarship/538

This Article is brought to you for free and open access by the Faculty Publications at Scholarship Archive. It has been accepted for inclusion in Faculty Scholarship by an authorized administrator of Scholarship Archive. For more information, please contact scholarshiparchive@law.columbia.edu. 
JOHN C. COFFEE, JR.

\title{
“TWISTING SLOWLY IN THE
}

\author{
WIND': A SEARCH FOR
}

\author{
CONSTITUTIONAL LIMITS ON \\ COERCION OF THE CRIMINAL \\ DEFEN D A N T
}

In the corridor outside Courtroom Four, Foster Clark approached the prosecutor. "I was wondering," he said, "are we really going to have to try this case?"

"Well," the prosecutor said, "that depends. He's dead on and gone to heaven, if that's what you mean. He doesn't have a prayer."

"I was wondering if we could work something out," Clark said. "I haven't really had a chance to talk with him, but I was wondering."

"So talk to him," the prosecutor said. "Find out where he stands, and call me."

$$
* * *
$$

"Look," the prosecutor said, "you know I can't answer that. I never know what the boss is going to want me to do. So why kid each other. My guess, my guess would be we ask for some jail if he pleads, and a lot of jail if he doesn't."

Professor John C. Coffee, Jr., is Professor of Law, Georgetown University Law Center.

AUTHOR'S NOTE: I served as Reporter for the second edition of the A.B.A.'s Standards on Sentencing Alternatives and Procedures (1979). Standard 18-6.9 ("Judicial Restraint") bears directly on the subject matter of this article, admonishing a sentencing court not to "take the initiative in seeking to obtain . . . a confession or to induce cooperation with the prosecution." See note 8 infra.

I wish to acknowledge my debt to my colleague, Professor Louis Michael Seidman, whose assistance in the preparation of this article has been invaluable.

(C) 1981 by The University of Chicago. 0-226-46433-4/81/1980-0014\$01.00 
"So he's got to talk," Clark said.

"Nope," the prosecutor said, he doesn't have to do a damned thing except decide which he wants to do more, talk and make somebody important for us, or go down to Danbury there and get rehabilitated."

"That's a pretty tough choice to make," Clark said."

George Higgins, the Balzac of our contemporary criminal justice system, here confronts Eddie Coyle and his friends with the prototypical dilemma of a criminal defendant. A potentially severe sentence faces Coyle. The price of leniency is cooperation with the prosecution. The cost of cooperation is the prospect of a violent retaliation if the party against whom the defendant informs learns of his assistance. ${ }^{2}$ Cloaking this bartering process is the language of rehabilitation, a rhetoric mocked by all and yet the common idiom in which the haggling is conducted. To the hard-nosed realist like George Higgins, this is the way the world works. Little fish implicate bigger fish; big fish must turn on still larger ones. If somewhere a defendant resists and refuses to trade evidence for leniency ("stand-up guys," in Higgins's parlance), he will serve long stretches of time in the penitentiary (as did G. Gordon Liddy). ${ }^{3}$

It is questionable whether the Supreme Court understands these dynamics-or wants to. Last Term, in United States $v$. Roberts, ${ }^{4}$ the Court turned once again to an issue on which it has vacillated for over a decade: the extent of the coercive pressure the government may bring to bear on a criminal defendant to secure a waiver of a constitutional right. ${ }^{5}$ Specifically, Roberts posed the question of

\footnotetext{
1 Higgins, The Friends of Eddie Coyle 181-82 (1972).

2 In United States v. Fatico, 441 F. Supp. 1285 (E.D.N.Y. 1977), Judge Weinstein took judicial notice of evidence of systematic reprisals by organized crime against governmental informants, including some twenty-five recent murders of such informants. Id. at 1288-89.

${ }^{3}$ For the facts of the Liddy case, see United States v. Liddy, 397 F. Supp. 947 (D.D.C. 1975). Liddy received a twenty-year sentence (with parole eligibility after six and two-thirds years). Coconspirator James McCord, who did cooperate, received a sentence of five years (with parole eligibility after one year). See Sirica, To SeT THE ReCORD STRAIGHT 84-120 (1979). See also note 7 infra.

${ }^{4} 100$ S. Ct. 1358 (1980).

${ }^{5}$ Cf. North Carolina v. Pearce, 395 U.S. 711 (1969); Blackledge v. Perry, 417 U.S. 21 (1974); Bordenkircher v. Hayes, 434 U.S. 357 (1978); Corbitt v. New Jersey, 439 U.S. 212 (1978).

Until recently, commentary on this topic has been relatively scarce. For recent thoughtful papers, see Uviller, Pleading Guilty: A Critique of Four Models, 41 L. \& C. ProB. 102 (1977); Schulhofer, Due Process of Sentencing, 128 U. PA. L. REv. 733 (1980); Nemerson, Coercive Sentencing 64 MiNN. L. REv. 669 (1980); Smaltz, Due Process Limitations on Prosecutorial
} 
whether the judge could increase the sentence where the defendant refused to cooperate with the prosecution and provide requested information. Unlike Higgins, the Court addressed this question with a tone of almost Victorian rectitude and limited its attention to the narrow issue of Fifth Amendment rights while carefully avoiding the issues below the surface. ${ }^{6}$

How should we evaluate the pattern Higgins describes and the Court evades? Highly variant characterizations are possible. To a civil libertarian, the practice of conditioning leniency on cooperation (or any condition requiring waiver of a constitutional right) means that the state is holding the defendant hostage and imposing unconstitutional conditions on the exercise of protected rights. Conversely, to a prosecutor, it is an efficient, low-cost means to secure otherwise unobtainable convictions. To the man in the street, this was the way Judge Sirica "broke" Watergate, ${ }^{7}$ and hence it has a niche in popular constitutional history. Nonetheless, to the Bar, the notion that a judge will be involved in the bartering process

Discretion in Re-Cbarging Defendants: Pearce to Blackledge to Bordenkireber, 36 WASH. \& L. L. REv. 347 (1979). On the distinct issue of burdens on the Fifth Amendment privilege, see Berger, The Unprivileged Status of the Fiftb Amendment, 15 A.C.L.R. 191 (1978).

' In order to find that failure to cooperate demonstrated a poor rehabilitative prognosis, Mr. Justice Powell analogized to the ancient offense of "misprision of felony" and announced that "gross indifference to the duty to report known criminal behavior remains a badge of irresponsible citizenship." $100 \mathrm{~S}$. Ct. at 1363 . One might have thought that a conviction for selling heroin would have alone demonstrated this "irresponsibility." It is difficult to believe that heroin dealers demonstrate potential for good citizenship by willingness to cooperate with prosecutorial authorities. More likely, their relative willingness is explained by fear of private reprisal if they inform; fear of a subsequent prosecution if they talk without use immunity; and fear of judicial reprisal at sentencing if they formally assert the privilege. Mr. Justice Powell seems to be seeking a cosmetic rationale for pressuring the defendant into cooperating. I will suggest that there are safer and less disingenuous rationales available.

${ }^{7}$ Judge Sirica's sentencing technique in the Watergate affair constitutes a virtual how-todo-it manual for a judge who wishes to coerce cooperation while avoiding appellate reversal. Sirica sentenced Liddy, Hunt, and four Cuban defendants to maximum terms of imprisonment under 18 U.S.C. $\$ 4208$ (b), which provides for a temporary maximum sentence pending a Bureau of Prisons study. Sirica then encouraged each defendant to "give serious consideration to lending [his] full cooperation to investigating authorities." He then quoted at length from the sentencing transcript of another case before a different court in which the court had said: "I am making no promise of leniency-but the sentence I impose will depend primarily on whether or not you cooperate with the permanent subcommittee on investigation of the United States Senate. .. "This message was repeated in substance several times, but always with the caveat that he held out "no promise or hopes of any kind. ..." See United States v. Liddy, 510 F.2d 669, 685 (D.C. Cir. 1974) (MacKinnon, J., dissenting).

Sirica could have used Federal Rule of Criminal Procedure 35 which permits a court to "reduce a sentence within 120 days after the sentence is imposed." This approach appears to be the more popular technique with most federal judges, because it permits the Court to give the defendant a "taste of prison" and because it maximizes the period in which the defendant has to consider whether to cooperate with the prosecution. 
and pressuring a defendant is profoundly disquieting. ${ }^{8}$ Yet the assertion that a criminal defendant should never be coerced, nor granted concessions for his cooperation, has relatively few adherents and, indeed, strikes many as quixotic.

Thus, in anticipation, Roberts $v$. United States seemed destined to be an important decision both for criminal law scholars and practitioners. Lower court decisions had split on whether a sentencing judge could expressly increase the sentence of a defendant who declined to cooperate with the prosecution. ${ }^{9}$ Was this an "impermissible purpose" ${ }^{10}$ Did it chill the defendant's Fifth Amendment privilege against self-incrimination? A decision either way seemed certain to implicate even more significant issues: could the state, for example, adopt a sentencing guideline which recommended a shorter sentence for defendants who plead guilty than for those who went to trial? ${ }^{11}$ If this were seen as chilling their right to a jury trial, how then was plea bargaining to be distinguished? Roberts ducked these issues by using a dubious procedural escape hatch. The Court found that the defendant had not properly preserved his Fifth Amendment rights. By expressly recognizing potential serious con-

\footnotetext{
${ }^{8}$ Indicative of the Bar's concern is Standard 18-6.9 of the A.B.A.'s MinimuM STANDARDS FOR CRIMINAL JuSTICE (2d ed. 1979) (hereafter ABA Standards). It reads in part: "Standard 18-6.9 Judicial Restraint. Although the sentencing court may appropriately take into consideration the defendant's admission of guilt or assistance given the prosecution in some circumstances, it is inappropriate for the court to take the initiative in seeking to obtain such a confession or to induce cooperation with the prosecution. . ." This Standard (which the author drafted) is new to the second edition and reflects a reaction to developments described in preceding footnotes.

${ }^{9}$ For earlier cases disapproving the use of cooperation as a sentencing factor, see United States v. Garcia, 544 F.2d 681, 684-86 (3d Cir. 1976); United States v. Rogers, 504 F.2d 1079 (5th Cir. 1974); United States v. Ramos, 572 F.2d 360 (2d Cir. 1978); Di Giovanni v. United States, 596 F.2d 74 (2d Cir. 1979). For earlier cases approving the use of such a factor, see United States v. Chaidez-Castro, 430 F.2d 766 (7th Cir. 1970). The lower court in Roberts had also approved the use of such a factor. 600 F.2d 815 (D.C. Cir. 1979).

${ }^{10}$ This argument had been reserved and expressly not considered two years earlier in United States v. Grayson, 438 U.S. 41, 53 (1978) (judge may consider at sentencing whether defendant's testimony at trial amounted to perjury). See also 18 U.S.C. $\$ 3577$ ("no limitation shall be placed on the information concerning the background, character and conduct of a person convicted of an offense" which the sentencing court may consider).

${ }^{11}$ Mr. Justice Stewart posed this issue in Corbitt, 439 U.S. at 277, asking, "Could a state legislature provide that the penalty for every criminal offense to which a defendant pleads guilty is to be one-half the penalty to be imposed upon a defendant convicted of the same offense after a non-guilty plea?" He answered in the negative. But Corbitt strongly suggests that, even if the pressure to plead guilty could not be made this strong, some form of sentencing credit can be given. For a more detailed proposal on how much credit could be incorporated within a guidelines sentencing system, see GoTTFREDSON, WILKINS, \& HoffMan, Guidelines For Parole and Sentencing 125-26 (1978).
} 
stitutional issues it wished to avoid, ${ }^{12}$ Roberts set the stage for a future controversy whose resolution the Court will have to undertake.

One could pause at length to question the waiver analysis used in Roberts. Its conclusion that the Fifth Amendment privilege is not "self-executing" was predicated on Garner $v$. United States, ${ }^{13}$ which contains language suggesting that the privilege is indeed selfexecuting in certain strongly coercive contexts. Arguably, the context of postindictment interrogations could supply a model illustration of the exceptions recognized by Garner. But this criticism is beside the point. On one of the very next occasions when an Eddie Coyle or a Winfield Roberts faces sentencing after the Court's requirement that the defendant either assert the Fifth Amendment or claim a fear of retaliation, competent counsel will promptly assert the privilege on their behalf. Roberts then provides an elaborate analysis that works for that case. But that escape hatch for the Court has been closed.

The post-Roberts issue is what happens next after counsel raises an objection in a timely fashion. Mr. Justice Marshall in dissent assumed that it would be "patently unconstitutional" to increase a sentence in retaliation for the exercise of a constitutional right. ${ }^{14}$ But this is too simple and ignores other predictable evasions. First, once the privilege is claimed, the court as a practical matter may still enhance the sentence in response to the claim so long as it observes the precaution of not saying that it is doing so. Only in rare cases have appellate courts been willing to infer unarticulated motives behind a court's sentence. ${ }^{15}$ Second, in some cases the

${ }^{12} 100 \mathrm{~S}$. Ct. at $1364-65$. ("These arguments would have merited serious consideration if they had been presented properly to the sentencing judge.")

13424 U.S. 648, 659-61 (1976). The Court responds to this exception in Roberts by saying that no such coercive "factor has been identified in this case." $100 \mathrm{~S}$. Ct. at 1364 n.6. But see note 2 supra on the strong possibility of retaliation. Prior to Roberts, the Court had recurrently distinguished and upheld self-reporting statutes which advanced a regulatory, noncriminal purpose by emphasizing that their focus was very different from constitutionally illegitimate statutes which demanded information from a "highly selective group inherently suspect of criminal activities." See California v. Byers, 402 U.S. 424, 430 (1971); Albertson v. S.A.C.B., 382 U.S. 70, 79 (1965); Marchetti v. United States, 390 U.S. 39, 47 (1968). Seemingly, there are few more "highly selective groups inherently suspect of criminal activities" than offenders awaiting sentence. Thus, Roberts suggests that the Court has now abandoned this line in one of the clearest cases where it might have applied to block the government's demand for information.

It 100 S. Ct. at 1367.

15 For a good treatment of this area and suggested reforms, see Note, $A$ Hidden losue of 
prosecution may be prepared to grant testimonial immunity. Defendant's dilemma then is twofold. (1) If he cooperates (or is even thought to have), he is exposed to a potentially violent private retaliation. (2) A court may still enhance the sentence it imposes (either consciously or unconsciously) once its suspicions are thus confirmed as to the defendant's prior criminal activities. In this sense, the privilege is uniquely ineffectual at sentencing because it protects only against prosecution on the basis of the testimony given and not against enhanced punishment. Indeed, the prosecutor has little need to prosecute the defendant based on the information compelled when, by calling it to the attention of the judge through the medium of the presentence report, it may have an even more immediate, material, and incapacitory impact on the defendant. My starting point therefore is the recognition that at present a request at sentencing for defendant's cooperation leads to an insolubly ambiguous situation: ${ }^{16}$ one simply cannot know whether the defendant is being penalized for the assertion of a constitutional right or, when he waives the right under these obviously coercive circumstances, if the sentence has been enhanced on the basis of the criminal activities thereby divulged. Nor will the traditional answer of the civil libertarian - that the testimony should be immunized-fully protect the defendant here. Whatever the form of immunity given, the peril of an enhanced sentence remains whenever the court may learn either of the testimony or the refusal to cooperate.

The Roberts context is far more interesting than the Roberts decision. Not only is a defendant at sentencing an inviting target for judicial and prosecutorial coercion, but the context shows the interaction among legal doctrines never rationalized or integrated by the Court. Four stand out: First, there is the modern doctrine of unconstitutional conditions which in theory denies government the power to condition receipt of a benefit (here, leniency) upon the waiver of a constitutional right (here, the Fifth Amendment). ${ }^{17}$ Under Garrity

Sentencing: Burdens of Proof for Disputed Allegations in Presentence Reports, 66 Geo. L.J. 1515 (1978). See also United States v. Harris, 558 F.2d 366 (7th Cir. 1977).

${ }^{16}$ A similar context of inherent ambiguity arises when the arrestee is silent after being informed of his right to silence under Miranda v. Arizona, 384 U.S. 436 (1966). Cf. Doyle v. Ohio, 424 U.S. 610 (1976) (denying prosecutor ability to impeach a testifying witness with his post-arrest silence because such silence was "insolubly ambiguous"). But see Jenkins v. Anderson, 100 S. Ct. 2124 (1980) (limiting Doyle).

${ }^{17}$ For a discussion of this doctrine and the problems the Court has had in applying it, see 
v. New Jersey, ${ }^{18}$ and subsequent decisions, ${ }^{19}$ it is constitutional orthodoxy that the defendant may not be subjected to even a civil sanction (such as dismissal from employment or prospective disqualification) for asserting the privilege. Indeed, as extended by Lefkowitz $v$. Turley, a "waiver secured under threat of a substantial economic sanction cannot be termed voluntary." 20 Thus, there is a strong argument that the defendant awaiting sentence is automatically entitled to use immunity with respect to statements made under the threat of an enhanced sentence. If, as the Court has said, the Fifth Amendment privilege is "intended to relieve claimants of the necessity of making a choice between incriminating themselves and risking serious punishments for refusing to do so," ${ }^{21}$ few contexts present this choice more starkly.

The effect of Roberts on this argument is uncertain. Although Roberts says the privilege is not "self-executing," the Court appears to mean that the judge can penalize unexplained silence rather than that the prosecutor may convict on the basis of coerced testimony. ${ }^{22}$ More troubling to this attempt to extend the Garrity principles to sentencing is Baxter $v$. Palmigiano, ${ }^{23}$ in which the Court permitted an adverse inference to be drawn at a prison disciplinary hearing when the inmate refused to testify because of the prospect of a criminal prosecution arising out of the same incident. ${ }^{24}$ If Baxter is applicable in the context of sentencing (as it may

Tribe, AMERICAN Constitutional LAw § 10-8 (1978). Cf. Sherbert v. Verner, 374 U.S. 398 (1963); Wyman v. James, 400 U.S. 309 (1971).

18385 U.S. 493 (1967).

${ }^{19}$ Lefkowitz v. Cunningham, 431 U.S. 801 (1977); Lefkowitz v. Turley, 414 U.S. 70 (1973); Sanitation Men v. Sanitation Comm'r, 392 U.S. 280 (1968); Gardner v. Broderick, 392 U.S. 273 (1968).

20414 U.S. at $82-83$.

21 Albertson v. Subversive Activities Control Board, 382 U.S. 70, 76 (1965).

22 A close reading of both Roberts and Baxter v. Palmigiano, 425 U.S. 308 (1976), suggests that the Court's real interest is in preserving tbe discretion of the judge or hearing examiner to induce cooperation, not in providing the prosecution with testimony on which it may indict the defendant. This theme is developed most clearly in Baxter, 425 U.S. at 318. See text infra, at notes 144-53.

${ }^{23} 425$ U.S. 308 (1976).

24 A criminal prosecution was pending in Baxter at the time of the disciplinary hearing. As a result, the First Circuit required that use immunity be granted him for statements made at the hearing. See 487 F.2d 1280, 1292 (1st Cir. 1973). This decision was remanded by the Court for reconsideration in light of the intervening decision in Wolff $v$. McDonnell, 418 U.S. 539 (1974). See Baxter, 418 U.S. 908 (1974). The First Circuit then changed its analysis and insisted that no adverse inference be drawn from the defendant's silence. See 510 F.2d 534 (1st Cir. 1974). 
be), it would suggest that the judge may penalize the defendant precisely because he has exercised the privilege. But even if the criminal defendant receives use immunity at the sentencing, his victory would be a Pyrrhic one, unless this incomplete protection is supplemented by additional safeguards to shelter him from judicial and prosecutorial reprisals. Little solace can be taken by the defendant who receives use immunity if the "immunized" testimony results in a twenty-year sentence instead of five.

The Court's use of rehabilitative theory presents a second example of how the sentencing context anomalously stands apart from the mainstream of constitutional law. Put simply, the Court continues in Roberts to rely on "rehabilitation" much as the drunk does on the light post: not for illumination, but for desperate support. ${ }^{25}$ Roberts says that the failure to testify is a symptom which the Court may use diagnostically in assessing the defendant's prospects for rehabilitation. ${ }^{26}$ This raises an obvious question: can the exercise of a constitutional right cause anyone, including the offender, to be judged a risk to society? Here, a familiar line of tension reappears: the conflict between rehabilitative purpose and constitutional rights, which once had been seemingly resolved largely in favor of the latter by the juvenile court decisions. ${ }^{27}$ But this same tension runs through the correctional field, and here the constitutional side has rarely won. ${ }^{28}$

A third and more important issue grows out of a different method for coercing cooperation. If for any reason the exercise of a right cannot be penalized, may its nonexercise be rewarded? Can leniency be distinguished from a penalty? Of course, in the standardless context of contemporary sentencing procedures, this distinction between pluses and minuses seems only a semantic one. But the case law has adamantly refused to acknowledge this elementary bit of legal realism. With a schizoid sense of righteous indignation, it has condemned the judge who adds a penalty but accepted as benign the judge who grants a concession in return for a waiver of the same right that a judge is prohibited from chilling. ${ }^{29}$

\footnotetext{
25 See text infra, at notes 118-30.

$26100 \mathrm{~S}$. Ct. at 1363-64.

${ }^{27}$ For a classic discussion of this tension, see AlLEN, THE BorderLaNd of CRIMINAL JUSTICE 33-34 (1964).

28 See, e.g., Grayson, 438 U.S. 41; Rummel v. Estelle, 100 S. Ct. 1133 (1980).

${ }^{29}$ See, e.g., United States v. Ramos, 572 F.2d 360, 363 n.2 (2d Cir. 1978) (concurring
} 
If this seems myopic, the remedy is still far from simple. Even if this distinction were rejected, the basic problem would remain that a sentencing court is under no constitutional obligation today to explain its sentence. ${ }^{30}$ Thus, the judge who sentences in silence will seldom meet reversal on appeal, and only the court that idiosyncratically insists on explaining that it is penalizing the defendant for his noncooperation will run afoul of Mr. Justice Marshall's simple rule that the exercise of constitutional rights may not be punished.

The issue whether leniency can intelligently be distinguished from a penalty under other circumstances and procedures remains a real one. In this light, the most important dispute between the majority and minority opinions in Roberts was the division over whether sentencing enhancements can be distinguished from sentencing concessions. Here, the majority opinion has the virtue of candor. In a footnote, the majority said simply: "We doubt that a principled distinction may be drawn between 'enhancing' the punishment imposed upon the petitioner and denying him the 'leniency' he claims would be appropriate if he had cooperated." ${ }^{31}$ In reply, Mr. Justice Marshall noted that this distinction is made every day in the federal courts. ${ }^{32}$ Unfortunately, this answer states the problem; it does not resolve it. The majority's skepticism at bottom rested more on doubts about the utility of appellate court intervention in sentencing decisions than on its distaste for a disingenuous distinction. Possibly, the majority believed that appellate review

opinion); United States v. Araujo, 539 F.2d 287 (2d Cir. 1976); United States v. Derrick, 519 F.2d I (6th Cir. 1975); United States v. Stockwell, 472 F.2d 1186 (9th Cir. 1974).

Some commentators have also felt that a principled distinction exists where the enhancement of sentence would exceed the "just deserts" ceiling on the punishment. See Nemerson, note 5 supra, at 737-38. I have elsewhere expressed my skepticism with the unreality of retributive theories and my preference for an egalitarian substitute. See Coffee, Repressed Issues of Sentencing: Accountability, Predictability and Equality in the Era of the Sentencing Commission, 66 GEO. L.J. 975 (1978). But here the problem with such a distinction involves its implementation. Absent a sentencing guidelines system, there is no real difference between pretending that the normal sentence is four years and granting a two-year concession for cooperation versus candidly ackowledging that the normal sentence is two years and enhancing it by two additional years for noncooperation.

${ }^{30}$ See Dorszynski v. United States, 418 U.S. 424 (1974) (failing to require a statement of reasons before incarceration of a juvenile). See also United States v. Harris, 558 F.2d 366, 374 (7th Cir. 1977), and Commentary to ABA Standard 18-6.6.

$31100 \mathrm{~S}$. Ct. at 1363 n.4. Two years earlier in Corbitt, however, the Court had little difficulty in drawing exactly this distinction between leniency and enhancement. 439 U.S. at 223-24.

32100 U.S. at 1370 n.9. 
will result not in less pressure on defendants but only in less candor from sentencing courts. ${ }^{33}$

Analysis of the metaphysical distinctions between leniency and penalties cannot be confined to the Fifth Amendment context. At this point, it becomes evident that there is latent in the Roberts context a fourth and even larger issue that may dwarf those encountered above: the chilling effect of judicial and prosecutorial practices on the criminal defendant's rights in general. For example, if the judge were, on Fifth Amendment grounds, denied the power to enhance the sentence for noncooperation, would this simply lead to the application of the same pressure on the defendant by the prosecutor, whose charging discretion and plea-bargaining leverage over the defendant are almost as great as that of the judge but whose actions are far less visible and reviewable? In addition, what distinguishes the defendant's Fifth Amendment right when certainly plea-bargaining and sentencing concessions can and do chill his right to a jury trial? Once these questions are raised, the scope and significance of the problems implicated by Roberts multiply rapidly. Never mentioned in it is the ambiguous body of case law that has dealt with these issues. In some decisions, such as Blackledge ${ }^{34}$ and Pearce, ${ }^{35}$ the Court has rejected "retaliatory" actions by the prosecutor and judge alike which chill the exercise of a criminal defendant's rights. In more recent cases, such as Bordenkircher $^{36}$ and Corbitt, ${ }^{37}$ the Court has allowed the state to place a substantial burden on the right to a jury trial. Because Bordenkircher candidly views the criminal defendant as a fair target for prosecutorial pressure but still treats Blackledge as a relevant precedent, the failure to reconcile the two decisions leaves a considerable amount of uncertainty. Depending on which is controlling, the state either can or cannot (1) subtract a year from its presumptive sentencing system for defendants who plead guilty, (2) add a year for defendants who forgo their right to appeal, or (3) otherwise coax and coerce the defendant into a variety of desired actions (e.g., restitution, cooperation, and confession).

\footnotetext{
${ }^{33}$ Empirical research has been skeptical of the efficacy of a statement of reasons requirement in generating a meaningful explanation of the sentence. See Zeisel \& Diamond, Searcb for Sentencing Equity: Sentencing Review in Massacbusetts and Connecticut, 4 AM. B. F. RES. J. $881,928-34$ (1977).

${ }^{34} 417$ U.S. 21.

${ }^{36} 434$ U.S. 357.

35395 U.S. 711.

37439 U.S. 213.
} 
In the twilight zone between Blackledge and Bordenkircher, pressure on the defendant to cooperate (as opposed to pressure on him to plead guilty) can be variously classified. The critical issue is whether the rationale of Bordenkircher can extend beyond legitimizing coercion which seeks a plea of guilty and reach also pressure directed at the waiver of other rights. To address this issue adequately, it is necessary to move beyond the limited holdings of either decision to seek a coherent normative theory which explains the constitutional limits on the coercive use of the state's legitimate discretionary powers. Not surprisingly, several such models are possible, and, less surprisingly, none is ideal. Two questions must be asked: (1) Does the model provide realistic protections that can be meaningfully implemented? (2) Does it recognize the state's legitimate interests-for example, does the model accept the central premise that the Supreme Court has followed since Santobello $v$. New York, ${ }^{38}$ that plea bargaining is not illegitimate per se, that pressure on the defendant is to some degree a necessary by-product of an adversarial system of criminal justice?

In Part I, I shall survey briefly the kinds of coercive pressure frequently imposed on a defendant of constitutional rights. In Part II, I shall turn to the constitutional commands and examine the bargaining rationale behind Bordenkircher and Corbitt, the diagnostic theory of Roberts, and the effect of Baxter on the Fifth Amendment privilege at sentencing. In Part III, the three major models which can potentially satisfy the criteria of fairness and efficiency will be surveyed and compared: (1) the Contract Model of Bordenkircher; (2) the Utilitarian Model that seems to underlie Matbews v. Eldridge ${ }^{39}$ and (3) the Dignitary Model now favored by many constitutional theorists. The last, a due-process balancing model, will be used chiefly to chart a line between Bordenkircher and Blackledge. But it also has relevance to the problem of defining the Fifth Amendment privilege. For years, the most sophisticated analysts of the privilege have been telling us that it is a cluster of different rights that sometimes have to be defined and applied through a balancing process. ${ }^{40}$ Indeed, given the rich philosophical tradition behind the right, it may prove to be one of the principal pillars on which a Dignitary

38404 U.S. 257 (1971).

39424 U.S. 319 (1976).

${ }^{10}$ See, e.g., Mansfield, Tbe Albertson Case: Conflict between the Privilege against SelfIncrimination and the Government's Need for Information, 1966 SUPREME COURT REVIEW 103; $f$. California v. Byers, 402 U,S. 424, $451-53$ (1971) (Harlan, J., concurring). 
Model for the criminal process can begin to be erected. In Part IV, a limited synthesis-the Model of Government Regularity-will be outlined.

\section{I. "Make Him an Offer He Can't Refuse": The Logic and Case Law of ChIlls, Threats, and Offers}

The Godfather knew that an offer could be a threat and that some offers could not be declined. Is the prosecutor in a position to make an offer similar to that of Don Vito Corleone?

\section{A. THE PRESSURE POINTS: A CONTINUUM OF COERCION}

What is under examination here is coercion by the state, directed at a defendant with the purpose or likely effect of inducing a defendant to forgo a constitutional right. Obviously, a case can be made that such pressure is patently unconstitutional, and at the outset of Bordenkircher, Mr. Justice Stewart seems to say as much: "To punish a person because he has done what the law plainly allows him to do is a due process violation of the most basic sort, . . . and for an agent of the state to pursue a course of action whose objective is to penalize a person's reliance on his legal rights is 'patently unconstitutional.' "41 This might seem dispositive but for the rest of Bordenkircher, where Mr. Justice Stewart explains why not every threat gives rise to impermissible punishment or retaliation. As Justice Frankfurter might have put it, to say that a practice is coercive only begins the analysis. ${ }^{42}$

From a doctrinaire perspective, every prosecutorial charging concession which is given in return for specific behavior by the defendant can be viewed as coercive. But the consequences of accepting this conclusion as the basis for a rule of prosecutorial conduct are frightening. When Alaska abolished plea bargaining in 1975 , it still permitted sentencing concessions to be given in certain "exceptional circumstances." 43 The nature of these circumstances was not defined, but a follow-up study conducted by the Alaska

\footnotetext{
41434 U.S. at 363.

${ }^{42}$ Cf. S.E.C. v. Chenery Corp., 318 U.S. 80, 85-86 (1943).

${ }^{43}$ See Rubinstein, White \& Clarke, The Effect of the Official Prohibition of Plea Bargaining on the Disposition of Felony Cases in Alaska Criminal Courts 69-70 (1979).
} 
Judicial Council found that the most common case where prosecutors continued to grant concessions under this special exception were those involving "sexual misconduct against children." 44 The prosecutor's motive was to minimize further trauma to the child by concluding the proceedings as rapidly as possible. Is this coercive? If it is not, it is hard to distinguish the not uncommon practice among prosecutors and judges of being lenient with a defendant who agrees to make restitution to his victims. ${ }^{45}$ Clearly, however, there is a quid being exchanged for a quo here. Finally, on an abstract level, the difference between these exchanges and probation conditions seems small. ${ }^{46}$ Not infrequently, a defendant is asked to waive Fourth or even First Amendment rights in return for a nonincarcerative disposition, and these conditions have been generally sustained so long as they satisfy a rule-of-reason test. ${ }^{47}$

Toward the middle of this continuum are better-known examples of coercion of the defendant. First, there is the traditional plea bargaining, a trade of sentencing leniency for a plea of guilty. Some studies find sentences between three and seven times as long are imposed on a defendant who goes to trial. ${ }^{48}$ The Roberts-type case

${ }^{44}$ Id. at 70.

45 Empirical observers have reported that "defendants offered concessions in return for state's evidence or other services or rewards feel as much compulsion as those who plead guilty." McDonald, From Plea Negotiation to Coercive Justice: Notes on the Respecification of a Concept, 13 Law \& Society Review 385, 390 (1979).

Professor Alschuler has argued that a fundamental distinction exists between bargains for a plea of guilty and those for services, information or restitution: namely, that the latter do not burden the exercise of a constitutional right and so are less objectionable. See Alschuler, Plea Bargaining and Its History, 79 Colum. L. Rev. 1, 4 (1979). This argument might have validity if the two offers were severable (i.e., one could plead guilty for a small discount and give services or restitution for a greater one), but for the defendant who wishes to maintain his innocence, it is rare that such a divorce can be arranged. As a result, the prosecutor's understandable desire to obtain testimony or restitution simply means that more pressure will be applied on the defendant to plead guilty; in addition, where incriminating testimony is sought, the defendant is being pressured to sacrifice two independent constitutional rights: the right to trial or appeal and the privilege against self-incrimination.

${ }^{16}$ See Note, Judicial Reviez of Probation Conditions, 67 CoLum. L. REv. 181 (1967); Note, Limitations on Trial Court Discretion in Imposing Conditions of Probation, 8 GA. L. REV. 466 (1974).

${ }^{47}$ See Malone v. United States, 502 F.2d 554 (9th Cir. 1974); $c$. Porth v. Templar, 453 F.2d 330 (10th Cir. 1971); Sobell v. Reed, 327 F. Supp. 1294 (S.D.N.Y. 1971).

${ }^{48}$ In the federal system, data compiled by the Administrative Office of the United States Courts shows that the average sentence weight for all reported offense classes was 4.7 for those defendants who pleaded guilty at arraignment and 13.5 for those convicted by a jury. See Administrative Office of the UNITEd States Courts, Federal Offenders in THE UNITED States DisTrICT CouRTS 55 (1971). These data are analyzed in Nemerson, note 5 supra, at 680 . 
where the prosecutor seeks either testimony or some form of valuable information in addition to a plea of guilty has not been as well studied, but it is the publicly expressed policy of the United States Department of Justice to enter into plea agreements in return for "the defendant's willingness to cooperate in the investigation or prosecution of others." 49

A third variety of coercion is pressure to forgo an appeal. Typically, this form of coercion emanates from the sentencing judge and is usually articulated in the form of a judicial query at sentencing as to whether the defendant is prepared to "come clean" and admit his guilt. In addition, he may be asked to "clean up" other outstanding charges or unsolved crimes. The result, of course, is that the defendant who bows to this request and goes through the requested ritual of contrition generally sacrifices his right to appeal and may subject himself to additional prosecutions. ${ }^{50}$

At the extreme end of this continuum are forms of pressure that produce truly agonizing dilemmas for a defendant. He may be asked, for example, to serve as undercover agent at extreme personal risk. ${ }^{51}$ Some studies have estimated that 90 percent or more of narcotics sales to police agents involve such undercover informants. ${ }^{52}$ Or the prosecutor may threaten to indict a defendant's spouse or children if he fails to cooperate. ${ }^{53}$

These examples suffice to illustrate some basic distinctions. First, a major difference exists between bargaining over the issue of guilt and bargaining on a quid pro quo basis over other issues. By definition, the first type of bargaining resembles a "zero sum" game: any gain by one of the contestants comes at the expense of the other. ${ }^{54}$

49 See U.S. Department of Justice, Principles of Federal Prosecution, Part D, 2(a); Part F, 27 CR. L. 3277 (1980) (discussing relevance of "defendant's willingness to cooperate in the investigation or prosecution of others" as a basis for a plea agreement).

${ }^{50}$ Courts have generally disapproved of this practice where it is explicit. See Thomas v. United States, 368 F.2d 941 (5th Cir. 1966); Bertrand v. United States, 467 F.2d 901 (5th Cir. 1972).

51 See Donnelly, Judicial Control of Informants, Spies, Stool Pigeons and Agent Provocateurs, 60 YALE L.J. 1091 (1951); Misner \& Clough, Arrestees as Informants: A Tbirteentb Amendment Analysis, 29 STAN. L. Rev. 713 (1977).

32 See Tiffany, Mcintyre, \& Rotenberg, Detection of Crime 252 (1967).

${ }^{53}$ See text infra, at notes 61-63.

54 A "zero sum" game is technically one in which the amount won by the winners exactly equals the amount lost by the losers. Such a rigorous criterion will rarely be satisfied in the criminal law context because the prosecutor's joy of victory could seldom equal the defendant's agony at defeat. However, in the less technical sense here intended, a "zero sum" game 
In the conventional plea bargain, prosecutor and defendant start negotiations with one seeking acquittal and the other a felony conviction on a serious charge. Gradually, a compromise is achieved at some intermediate point (perhaps a plea to a charge carrying a modest maximum sentence). In these negotiations, each side in theory can be expected to evaluate the strength of its position and to make concessions grudgingly, based on the possibility that its initial position might not be sustained at trial. ${ }^{55}$ The key premise to Bordenkircher is that such negotiations are a highly reliable means of anticipating the likely result of a trial and so provide a dependable substitute. ${ }^{56}$

In contrast, consider the bargaining process over the issue of cooperation. Both sides may be seeking to maximize different goals or to avert different losses. The prosecutor, for example, may consider a defendant of little significance compared to the possibility of convicting a major ringleader, and so he may be willing to trade dismissal of the indictment or some similarly lenient disposition in return for cooperation. Correspondingly, the most serious loss facing the defendant may not be conviction on the highest charge arguably sustainable, but rather the danger of retaliation if he informs. Alternatively, the defendant may decide to cooperate fully in order to receive a more lenient disposition than a simple discounting of the odds on conviction would warrant. Possibly, the defendant will do

can also mean one in which one party may only improve his position at the expense of the other. Thus, an adversarial contest is normally "zero sum" in this sense because the prosecutor's gain comes at the defendant's expense: any disposition greater than an acquittal improves the prosecutor's position and lessens the defendant's. But the contest is no longer zero sum if other factors are being considered: for example, the defendant may not see a plea of guilty as a defeat if it averts the prosecution of relatives or if the sentence imposed has already been served through pretrial confinement. Similarly, a dismissal is not a loss to the prosecution if the defendant agrees as the result of a bargain to implieate more important figures or to abandon a civil action against the state.

is In practice, however, the defense counsel does not have a sufficient identity of interests with his client for this to be true. Rather, he too often has a strong interest in a speedy plea bargain. See Alschuler, Tbe Defense Attorney's Role in Plea Bargaining, 84 YALE L.J. 1179 (1975).

56 From the "rational actor" perspective, which assumes that the parties act on their estimates of the likely results at trial, defendants who go to trial must fall into one of two categories: (1) "risk preferrers" who are predisposed to gamble in the face of uncertainty, and (2) clients whose attorneys have different estimates as to the outcome of a trial than do the prosecutors. See Matheny, Negotiation and Plea Bargaining Models: An Organizational Perspectize, 2 LAw \& PolicY Q. 267, 273 (1980). In this perspective, the bargaining process serves as a useful "reality learning" mechanism by which the differing assessments on conviction probabilities are brought closer together as both sides test the strength of their case and learn information in the possession of their adversary. Id. at 277. 
so by perjuring himself or by tailoring his testimony so that it satisfies the prosecutor's needs in another criminal prosecution. Thus, both sides maximize their own ends: the defendant receives leniency or averts a greater loss, the prosecutor gains important evidence, and the cost is externalized and borne by a third party (a defendant in another action). Either way-whether the defendant decides to cooperate or to resist and go to trial-the parties' assessment of their relative advantage is skewed by factors unrelated to the narrow issue of the likelihood of conviction. ${ }^{57}$ As a result, the prosecutorial threat of an increased penalty cannot be assumed to produce the same efficient discounting of the risk of conviction and incarceration as it may in the case of a "zero sum" negotiation.

In some cases, "non-zero-sum" bargaining also provides a considerable risk of truth distortion. Two examples are illustrative. During occasional lapses into candor, prosecutors have acknowledged that they will seek to deny bail to defendants whom they wish to have cooperate. ${ }^{58}$ This can result in forcing a defendant to serve all or a substantial portion of his likely sentence before his trial. Since this pretrial time must be credited against the sentence imposed, ${ }^{59}$ an innocent defendant may find that he has already served his sentence and can obtain virtual immediate release by pleading guilty. ${ }^{60}$ In contrast, a protestation of innocence may result in continued pretrial confinement. In this "Catch-22" world in which confession leads to release more quickly than does innocence, the prosecutor has the same leverage over the innocent as he does over the guilty.

${ }^{57}$ In Bordenkircber v. Hayes, 434 U.S. 357 (1978), the Court recognized that in some instances factors extrinsic to the trial's likely outcome could skew the defendant's assessment of whether to plead guilty. Id. at n.8. In this light, although the Court emphasized that a plea of guilty is normally a reliable substitute for a trial, it can be argued that its holding does not apply to non-zero-sum bargaining.

${ }^{58}$ Recently, federal prosecutors in the District of Columbia announced a new policy of prosecuting lesser drug offenders in Superior Court instead of in United States District Court because it was easier to obtain high bail or preventive detention and to revoke probation in Superior Court. Both these sanctions, they further announced, were to be used in the future to induce cooperation by lesser defendants. See U.S. Stiffens Drug Sentencing in District, WASH. Post, July 31, 1980, p. A-1, at A. 12 (quoting Assistant U.S. Attorney Lawrence Barcella, Jr.).

${ }^{59}$ See 18 U.S.C. $\$ 3568$ (granting credit against the sentence for pretrial detention).

${ }^{60}$ This would be an example of a non-zero-sum outcome because at the time the defendant accepts the bargain he gains release while the prosecutor gains a conviction (and possibly cooperation). Both thus improve their situation and neither's gain is necessarily the other's loss. 
This is also true in the not infrequent case where the prosecutor threatens to prosecute relatives or the spouse of a defendant if the defendant does not cooperate and/or plead guilty. ${ }^{61}$ Here, because the injury to his relatives may be perceived by the defendant as a more serious loss than his own conviction, the pressure can be sufficiently truth distorting to result in a plea of guilty even when the probability of conviction is relatively low. Nevertheless, courts have generally failed to note this distinction, and cases can be found in which defendants have entered pleas that may be more the product of a Sydney Carton-like sense of nobility than of guilt. For example, in Latham $v$. State ${ }^{62}$ the defendant was a father who had pleaded guilty in return for a prosecutorial promise of probation for his sons (who were needed at home to care for their invalid mother). In Kent v. State, ${ }^{63}$ the defendant was similarly denied permission to withdraw his plea where he had apparently pled guilty only after the prosecutor threatened to indict his fiancée as a coconspirator.

In the forgoing cases, the truth-distorting impact of the pressure is clear. But in other cases of non-zero-sum bargaining, the dynamics are more complex. In the case where the prosecutor demands cooperation as the price for acceptance of a plea bargain, the defendant may sufficiently fear revenge by the subject of his testimony that he feels compelled to reject the deal and go to trial even though he realizes his chances of acquittal are poor. Here the pressure actually reduces the possibility of a nonlitigated outcome. In the more typical case, however, where the prosecutor offers a modest concession for a plea and a substantial greater concession for cooperation, ${ }^{64}$ the disparity between the penalties following a conviction and a plea increases in a manner that can be truth distorting.

61 This practice is apparently frequent enough to have been addressed by the American Law Institute's Model Code. See ALI, MODEL Code of Pre-ARralgnMent Procedure, COMMENTARY TO $\$ 350.3,614-15$ (1975).

62439 S.W.2d 737 (Mo. 1969) (collecting cases); see also State v. Baumgardner, 443 P.2d 511 (N.M. 1968).

63272 F.2d 795 (1st Cir. 1959). A few decisions have acknowledged the possibility that such a threat could vitiate the voluntariness of the plea, but they have generally found the plea to have been adequately voluntary. See United States v. Tursi, 576 F.2d 396, 398 (1st Cir. 1978); Crow v. United States, 397 F.2d 284, 285-86 (10th Cir. 1968); Cortez v. United States, 337 F.2d 699, 701-02 (9th Cir. 1964). Review of all the facts and circumstances seems to focus most heavily on the evidence of the accused's guilt and less so on the pressure applied.

64 It would be simplistic, however, to assume that determinations by trial are more accurate than those by plea. Although the balance of advantage is tipped toward the defendant at 
The basic calculation for a defendant who is a rational actor is a relative one: the expected cost to him of a conviction following trial versus that of a plea of guilty. When the prosecutor threatens either an enhanced penalty or the indictment of others who are of concern to the defendant, he is raising the cost of trial, and this can be truth distorting. When he demands cooperation or some other act by the defendant which could elicit a reprisal, he is raising the cost of a plea. To the extent that the cost is raised and compensating concessions are not given, it encourages the defendant to litigate, and this is arguably a truth-enhancing result. ${ }^{65}$ Put differently, when the prosecutor threatens severity, he is raising the quid; when he asks for the cooperation, he is raising the quo he wants in return. By definition, as the latter rises to approach the former, the net pressure on the defendant to plead guilty declines, even though the aggregate may increase.

In both cases, however, so long as the bargaining is of the "nonzero-sum" variety in which the parties are bartering over matters unrelated to the likelihood of conviction, the results inherently tend to be more erratic and less reliable as a substitute for a litigated outcome. Reliability is lost either because (a) the plausibility of the threat is no longer tied to the likelihood of conviction (such as when the prosecutor threatens indictment of the defendant's relatives), or $(b)$ the prosecutor offers so great a discount that conviction itself carries little deterrent value (i.e., immediate probation is assured). Erratic results also become inevitable from this bargaining process because there is no recognized rate of exchange between the various threats the prosecutor is making; that is, additional years in prison, the prospect of private retaliation, and the suffering caused to relatives are all distinct injuries that cannot be translated into a common denominator. Thus, even if the same threat is made to all defendants, some are exposed to great pressure and some to relatively little depending on the individual character of each defendant.

From the prosecutor's point of view, a basic condition of the "zero-sum game" analogy is that he regard an acquittal as a total defeat; he compromises with the defendant based on the likelihood

trial so as to ensure fewer erroneous convictions (i.e., "false positives"), there will also be more erroneous acquittals of the factually guilty (i.e., "false negatives").

${ }^{65}$ See, e.g., MacDonald v. Musick, 425 F.2d 373 (9th Cir. 1970); Dixon v. District of Columbia, 394 F.2d 966 (D.C. Cir. 1968). Both decisions strongly disapprove of such conduct by the prosecutor. 
of acquittal. But in some circumstances an acquittal is not a loss for the prosecutor. For example, when he threatens the indictment of a relative or spouse of a defendant, it may often be the case that the relative is so minor and peripheral a figure that the prosecution would not be commenced but for the value of such a threat against the principal defendant. If so, the prosecutor is in effect using a counterfeit currency since the concessions made have no cost to him. Whenever the prosecutor is in a position to make such costless concessions, the leverage he has over the defendant seems unfair.

Another example of this pattern are those cases in which the prosecutor's charging and plea-bargaining discretion appears to have been influenced by civil actions the defendant had filed. ${ }^{66} \mathrm{~A}$ disposition of the criminal action satisfactory to the defendant may be conditioned on a resolution of the civil action favorable to the government. Here, dismissal of the criminal case is not really a loss to the prosecutor. Truth distortion is obviously possible in this case since most defendants are unprepared to take the risk of a criminal conviction to secure a civil judgment. Traditionally, courts have found this type of prosecutorial extortion to be improper, but in one recent case a federal court of appeals found a clear attempt by the government to trade dismissal of the criminal action for a defendant's abandonment of his civil case to be within the Bordenkircher zone of fair adversarial negotiations. ${ }^{67}$

Still another variation is the practice in some jurisdictions of denying leniency to defendants who make pretrial motions. ${ }^{68}$ The intent behind such a "no-motion" rule may be simply an effort by the prosecutor to encourage the defendant to plead guilty and would seem to be clearly within the scope of Bordenkircber. But it can have a considerably broader purpose. For example, the prose-

${ }^{66}$ United States v. Litton Systems, Inc., 573 F.2d 195 (4th Cir. 1978). For a critical commentary on this case, see Smaltz, Due Process Limitations on Prosecutorial Discretion in Re-Cbarging Defendants: Pearce to Blackledge to Bordenkircber, 36 WASH. \& LEE L. REV. 347 (1979).

${ }^{67}$ As of a recent date, it was the policy of the United States Attorney for the District of Columbia to deny probationary "First Offender Treatment" to otherwise qualifying defendants who litigated any issue in their case. See United States v. Smith, 354 A.2d 510 (1976). My information as to this policy comes from my colleague, Professor Louis Micbael Seidman, who had served in the Public Defender Office for the District of Columbia.

${ }^{68}$ Note, however, that some constitutional violations can be collaterally attacked even after a plea of guilty. See Menna v. New York, 423 U.S. 61 (1975). Thus, there is an important limit on prosecutorial pressure in this rule because the prosecutor gains nothing if the defendant is entitled to assert the constitutional violation after he has received a concession for pleading guilty. See text infra, at note 211 . 
cutor may recognize that the constitutionality of a particular statute is open to challenge. To avoid the issue being raised (since it could affect numerous other prosecutions), he could condition leniency (or promise severity) so as to prevent the challenge from being made. ${ }^{69}$ To be sure, a defendant may be able to exploit this issue and secure a more favorable disposition than the facts of his case warrant, but conversely the prosecutor may threaten extreme severity in order to protect interests extrinsic to the specific case. Either way, there is a harm visited upon the public by this private settlement between the prosecutor and the defendant, because the government's interest usually lies in the earliest resolution of the constitutional issue (particularly if the statute may be invalidated retroactively).

Other kinds of linkages may be sought by the prosecutor between the issue of guilt and unrelated issues. For example, the prosecutor may wish to deter a defendant from seeking bail and might threaten to reindict if a defendant does so. Or he may seek to deny bail unless the defendant cooperates. Regardless of which way the linkage works, in neither case is there any logical relationship between the issue of the defendant's entitlement to bail and the issue of his guilt. But in one recent court of appeals decision involving allegations of prosecutorial retaliation against a defendant for obtaining bail on appeal, there is again a suggestion that Bordenkircher shelters this type of bargaining as well. ${ }^{70}$

${ }^{69}$ See Brunk, The Problem of Voluntariness and Coercion in the Negotiated Plea, 13 LAw \& SocIETY REv. 527, 548 (1979). Such an argument, however, presupposes that we can determine what a "normal" sentence range would have been. Although it is not difficult to describe the Bordenkircher sentence (e.g., life) as outside the "normal" range, this article will argue that in the more typical case such a determination cannot be reliably made absent special institutional arrangements involving sentencing guidelines and procedures to cancel prosecutorial overcharging; these are discussed in the final section of this article. Given such institutional arrangements, however, it will be argued that it is sometimes possible to distinguish "offers" from "threats" because a background scale exists by which to gauge the normal sentence absent the special factor motivating the threat or offer.

${ }^{70}$ Recent empirical research suggests that experienced prosecutors and defense attorneys tend to form stable "work groups" in which the bargaining follows a normal tariff schedule of concessions and enhancements based on mutually accepted notions of what a normal sentence is. See Matheny, note 56 supra; EISENSTEIN and JACOB, Felony JUSTICE (1977); HeumanN, Plea Bargaining (1978). In this perspective, resort to an extra ordinary threat is generally unlikely unless the prosecutor has special interests transeending the individual case (such as the desire to gain information for a more important ease).

This "work group" perspective then provides another basis for distinguishing offers from threats: "offers" are not threats where botb sides have a common conception of what the "normal" sentence for the defendant would be and the offer simply gives a discount off this 
In short, to the extent that the prosecutor's interests extend beyond that of securing a conviction in the instant case, he has an incentive to link issues even though the public interest may lie in their separate resolution. Although Bordenkircher stressed what it termed "the simple reality that the prosecutor's interest at the bargaining table is to persuade the defendant to forgo his right to plead not guilty,"71 reality may be less simple: the prosecutor's interest is often less to force a plea than to tie its acceptance to something else.

More could be said about the bargaining tactics of the rational prosecutor, ${ }^{72}$ but my objective has been to set the stage for the analysis that will follow. Thus, it is important to distinguish prosecutorial pressure from judicial pressure. Pressure from the court to abandon an appeal may seem highly similar to prosecutorial pressure to plead guilty: both typically involve the same bilateral exchange-leniency for an acknowledgment of guilt and a consequent cost saving to the state. But there is no comparison in terms of their relative leverage over the defendant. Judicial pressure almost always comes after conviction, and thus, unlike the prosecutor's threats, it cannot be discounted by the likelihood of conviction. In addition, while the prosecutor may recommend a severe sentence, its impact is only advisory. Judicial coercion is far more sinister. Not only does the court generally have wide and unreviewable discretion at sentencing, but (in a nonjury case) it can vastly affect the odds on a successful appeal by its findings of fact. Even in a jury case, a defendant knows that the likelihood of reversal on appeal is small, and thus there is much less of a discount that may be applied to a judicial request for cooperation. All these factors, of course, make judicial pressure potentially more truth distorting than prosecutorial threats. Although both the court and the prosecutor may have an incentive to threaten and bargain that is inversely proportional to the strength of the case against the defendant, ${ }^{73}$ judicial pressure is more self-insulative because it cannot be discounted in the manner of prosecutorial pressure.

mean sentence. See also text at note 150 infra for an additional perspective on differentiating offers from threats.

${ }^{71}$ See United States v. Andrews, 612 F.2d 235, 245-47 (6th Cir. 1980) (Merritt, J., concurring).

72434 U.S. at 364.

${ }^{73}$ Not discussed in the forgoing analysis is a third factor which must be considered in addition to the severity of the penalty and the probability of conviction. This is the factor of risk aversion: the risk-averse defendant tends to focus on the severity of the maximum 
Before I rush to the conclusion that judicial pressure is therefore illegitimate, however, I must acknowledge that the court, unlike the prosecutor, is entitled to administer punishment and to impose preventive, incapacitative, and restitutionary probation conditions. ${ }^{74}$ Coercion directed at these objectives must be distinguished from coercion which seeks the waiver of a right. Once again, the object is to distinguish legitimate from illegitimate pressure.

Two different legal models today rationalize judicial and prosecutorial pressure: the bargaining model of Bordenkircher and the diagnostic model of Grayson and Roberts. Each has different limits.

\section{B. THE CASE LAW: WHAT HATH BORDENKIRCHER WROUGHT?}

In 1968, the Court wrote boldly that if the "purpose or effect" of a statute or practice is "to chill the assertion of constitutional rights by penalizing those who choose to exercise them" the result is "patently unconstitutional."75 United States $v$. Jackson invalidated a statute permitting the imposition of the death penalty only upon the recommendation of the jury since it had the effect of permitting the death penalty only when the defendant declined to plead guilty. ${ }^{76}$

Jackson was the first of a trilogy which seemed to generalize a chilling-effect doctrine as a major proponent in the constitutional law of criminal procedure. The following year the Court in Pearce ${ }^{77}$ extended the doctrine to apply to all sentencings (rather than simply to capital cases) and to judicial practices as well as to statutes.

penalty and the risk preferrer on the probability of conviction. See ElzINGa \& BRITT, THE ANTITRUST PENALTIES: A STUdY IN LAW AND Economics 120-29 (1976). For the sake of simplicity, I assume the defendant is risk neutral. But to the extent that he may be risk averse, the prosecutor's ability to force false self-condemnation increases. Cf. Polinsky \& Shavel, The Optimal Tradeoff between tbe Probability and Magnitude of Fines, 69 AM. ECON. REV. 880 (1979).

${ }^{74}$ Professor Alschuler has concluded that prosecutors frequently compensate for the weakness in their case by offering larger sentencing concessions. Indeed, he concludes that prosecutors view "the strength or weakness of the state's case . . . [as] . . . the most important factor in the task of bargaining." See Alschuler, Tbe Prosecutor's Role in Plea Bargaining, $36 \mathrm{U}$. Chi. L. Rev. 50, (1968). See also Newman, Conviction: the Determination of GUILT OR INNOCENCE WITHOUT TRIAL 67-75 (1966).

${ }^{75}$ United States v. Jackson, 390 U.S. 570, 581 (1968).

${ }^{76}$ For a more detailed analysis of Jackson and its successor cases, sec Seidman, Factual Guilt and the Burger Court: An Examination of Continuity and Cbange in Criminal Procedure, 80 Colum. L. REv. 436, 472-83 (1980).

77395 U.S. 711. 
Pearce involved a harsher sentence which had been imposed following a retrial after a successful appeal. Viewed strictly, the defendant faced a considerably more remote chill than in Jackson, since an unsuccessful appeal cost him nothing and a successful appeal could produce a net detriment only if he were retried and reconvicted. Nonetheless, the Court went well beyond holding that a sentence imposed as a vindictive act of retaliation violated due process. Instead it fashioned a broad prophylactic rule that harsher sentences after a successful appeal were proscribed, except where objective information involving conduct by the defendant subsequent to the original sentence became available. To justify this result, the Court again used a broad brushstroke: "[S]ince the fear of such vindictiveness may unconstitutionally deter a defendant's exercise of the right to appeal or collaterally attack his first conviction, due process also requires that a defendant be freed of apprehension of such a retaliatory motivation on the part of the sentencing judge." $"$ In short, the test was not the actual fact of vindictiveness but the reasonable fear of it. But if a reasonable fear gave rise to constitutional violation, how could plea bargaining be rationalized?

A conflict between Pearce's "reasonable apprehension" test and the reality of plea bargaining became inevitable with the Court's 1974 decision in Blackledge ${ }^{79}$ that the Jackson/Pearce formula applied to prosecutors as well. Blackledge grew out of North Carolina's two-tier trial system under which a convicted defendant had an absolute right to appeal and to obtain a trial de novo in the superior court. In Blackledge, the defendant exercised this right only to have the prosecutor respond by reindicting him for a felony based on the same conduct that had resulted in a misdemeanor conviction below. Following Pearce, the Court again adopted a prophylactic rule. Because "upping the ante" in this fashion gave the appearance of vindictiveness, the prosecutor was precluded from filing increased charges on the trial de novo. Once again the Court emphasized that the actual motive was irrelevant and only the appearance counted. ${ }^{80}$

While the Jackson/Pearce/Blackledge trilogy seemed to codify a comprehensive prohibition against chilling the criminal defendant's

${ }^{78} \mathrm{Id}$. at 725 . In a footnote, the Court noted that the "existence of a retaliatory motivation would, of course, be extremely difficult to prove in any individual case," but concluded on the basis of empirical surveys that such a chilling effect was clear in tbe aggregate. Id. at 725 n.20.

79417 U.S. 21.

${ }^{80} \mathrm{Id}$. at $27-28$. 
rights, this was only half the story. A parallel line of cases was developing over this same period which rationalized coercion so long as it was directed at obtaining a plea of guilty. In 1970, two years after Jackson, the Court in Brady ${ }^{81}$ again faced the same statute which still only authorized the death penalty in cases where the defendant stood trial. Brady, however, had pleaded guilty, and this, the Court decided, distinguished his case from that of Jackson, even though the Court assumed arguendo that the plea was motivated by a desire to escape the enhanced punishment. ${ }^{82}$ Other decisions then generalized Brady's result into a theory that the plea of guilty had a preclusive effect because it was a reliable indicator of factual guilt. ${ }^{83}$ Thus, the plea could cut off all subsequent attempts to establish the defendant's factual innocence. The critical problem with this line of reasoning was, of course, that the plea of guilty may have been coerced by the threat of enhanced punishment. Such a theory failed to explain why the plea context in Brady was so different from the appeal context in Pearce that the first defendant could withstand pressure but the second could not. ${ }^{84}$

In 1978 , in Bordenkircher, ${ }^{85}$ the Court made a serious effort to rationalize the inconsistencies that Brady, Jackson, and Blackledge had created. Defendant Hayes faced a term of between two and ten years for uttering a forged instrument in the amount of $\$ 88.30$. The prosecutor had offered to recommend a term of five years in return for a plea of guilty, but he had also threatened to indict the defendant as a habitual offender (where conviction would carry a mandatory life term) if Hayes went to trial. Hayes stood firm, the prosecutor was true to his word, and, on conviction, a life term was imposed. Since Hayes had not entered a plea, his counsel could analogize his case to Jackson and claim Brady was irrelevant. In 1971, however, the Court had decided in Santobello ${ }^{86}$ that the prosecutor must live up to his promises made in plea bargaining, and in Bordenkircher it saw the mirror image: if the prosecutor must honor his

81397 U.S. 742 (1970).

${ }^{82} I d$. at 750 .

83 See McMann v. Richardson, 397 U.S. 759 (1970); Tollett v. Henderson, 411 U.S. 258 (1973); $c f$. Henderson v. Morgan, 426 U.S. 637, 649 n. 1 (1967) (White, J., concurring). The Court's twists and turns in this area are ably described in Seidman, note 76 supra, at 470-83.

${ }^{84}$ Confusing matters even further, the defendant in Blackledge pleaded guilty at his second trial, but was not cut off by this plea from raising his constitutional claim before the Court, while the defendant in Brady had earlier been so precluded.

85434 U.S. 357.

86404 U.S. 257. 
bargains, so could he enforce them by carrying out his threat. To uphold plea bargaining, Bordenkircher had then to reinterpret the Jackson/Pearce/Blackledge trilogy. It drew essentially three distinctions: (1) There is a "mutuality of advantage" to plea bargaining - that is, the defendant is not simply coerced as in Pearce but obtains leniency which might otherwise be unavailable (the "Mutual Benefit Premise"). ${ }^{87}$ (2) There is "no element of punishment or retaliation in plea-bargaining so long as the accused is free to accept or reject the prosecution's offer" (the "Fair Offer Premise"). ${ }^{88}$ (3) Because the defendant has counsel, his interests are protected and the process essentially produces the same result as a trial but in a more efficient and expeditious fashion (the "Reliable Substitute Premise"). ${ }^{89}$

The Mutual Benefit Premise seems the shallowest since the "benefit" to the defendant may consist only of immunity from the enhanced sentence that otherwise might have been imposed. Conceptually, the "benefit" does not exist apart from the threat. In this sense extortion and blackmail might also be described as providing a mutual benefit to the two parties. But the concept of mutual benefit cannot be totally dismissed. To be meaningful, however, this premise needs some intermediate measure (e.g., if a sentencing guideline system promulgated a standard term for the "normal" case, then gave a credit for a plea of guilty but also added an increased term for the clearly frivolous defense, it might be plausible to view the process as giving the defendant a desirable choice).

The Fair Warning Premise is the critical change ushered in by Bordenkircher. Essentially, the concept of chilling effect is narrowed, and the defendant's right is, not to stand trial undeterred by the prospect of additional punishment, but rather to be free of unforeseen retaliation. Thus, the earlier trilogy of Jackson/Pearce/Blackledge is now seen as a set of cases involving the "unilateral imposition of a penalty upon a defendant who had chosen to exercise a legal right." 90 In contrast, during plea bargaining the defendant has an opportunity to accept or reject. In short, the concept of "retaliation" is cut back to mean "upping the ante" without a prior warning and a chance to negotiate. Undeniably, this is a difference between Blackledge and Pearce on one hand and Bordenkircher on the other, but

${ }^{87} 434$ U.S. at 363.

${ }^{80}$ Ibid.
${ }^{88}$ Ibid.

90434 U.S. at 362 . 
whether it is a satisfactory distinction (at least standing alone) seems questionable. If followed literally, for example, it would imply that the sentencing judge in Pearce could first warn the defendant that he would impose a harsher sentence if there were a successful appeal and retrial and then do so. If Pearce is distinguished on the grounds that the judge is subject to different standards, the prosecutor might be allowed, after Bordenkircher, to promise to do exactly what he did in Blackledge, so long as he gave fair notice of his intent to do so. ${ }^{91}$ Nor does the Fair Warning Premise distinguish Jackson since the defendant there knew of the threat and had the opportunity to plead guilty (and secure the "mutual advantage" of escaping the death penalty).

The Reliable Substitute Premise relates directly to my prior survey of bargaining tactics since it assumes that a defendant, assisted by competent counsel, can accurately discount the risk of conviction and plead guilty if the odds on conviction strike him as too high. Mr. Justice Stewart's phrasing of this theme deserves special scrutiny: "Defendants advised by competent counsel and protected by other procedural safeguards are presumptively capable of intelligent choice in response to prosecutorial pressure, and unlikely to be driven to false self-condemnation." 92

In short, Mr. Justice Stewart is chiefly saying that the factually innocent do not plead guilty. As a behavioral premise, this observation has merit only in the cases of some classes of defendants. ${ }^{93}$ But, there is an ambiguity in the Stewart statement. He is saying, too, that a counseled defendant will make an "intelligent choice." These two propositions are quite different and sometimes contradictory. On a rational basis, it can be the "intelligent" choice to engage in "false self-condemnation." Indeed, the recognition of this possibility seems to underlie the Court's earlier acceptance in North Carolina $v$. Alford ${ }^{94}$ of a guilty plea under which the defendant

${ }^{91}$ This would be a form of zero-sum bargaining conducted with fair notice and hence not retaliatory under Bordenkircber's reasoning. One can, however, seek to restrict Bordenkircber to preconviction proceedings and Blackledge to the postconviction context. See Andrews, 612 F.2d at $245-47$, 256. See also Jackson v. Walker, 585 F.2d 139 (5th Cir. 1978) (restricting Blackledge).

92434 U.S. at 363.

${ }^{93}$ For middle-class defendants, there are some empirical data which suggest that the stigmatization incident to conviction is a more important deterrent than the prospect of incarceration. Sec Nagin \& Blumstein, Tbe Deterrent Effect of Legal Sanctions on Draft Evasions, 29 STAN. L. Rev. 241, 269-70 (1977).

94400 U.S. 25 (1970). See also McCoy v. United States, 363 F.2d 306, 308 (D.C. Cir. 1966); Tremblay v. Overholser, 199 F. Supp. 569, 570 (D.D.C. 1961). 
continues to assert his innocence. Declining to be paternalistic, the Court in Alford saw it as largely up to the defendant to decide his own advantage and did not require the trial court to reject the plea where the defendant sought simultaneously to deny his guilt.

Clearly, the more the prosecutor in Bordenkircher or the statute in Jackson increases the threatened penalty for going to trial, the more the "intelligent choice" for the rational actor tilts toward pleading guilty. For example, if we take a case in which the prosecutor has only a 20 percent chance of securing a conviction and in which he offers a one-year sentence for a plea but threatens a ten-year sentence if there is a trial, the rational actor may discount the ten-year sentence times the 20 percent probability and see it as the expected equivalent of a two-year sentence or twice the penalty for pleading guilty. ${ }^{95}$ This probably will not be the analysis that the typical middle-class defendant would adopt since the empirical evidence suggests that the stigmatization incident to conviction is the primary sanction against such defendants, one which outweighs the length of incarceration. ${ }^{96}$ For the second offender (and for the offender with low social status), however, stigmatization is of less concern. ${ }^{97}$ Thus, for these offenders and for the defendant who is simply risk averse, ${ }^{98}$ the Reliable Substitute Premise becomes increasingly shaky. Indeed, the finding of a well-known statistical study to the effect that a substantial percentage of defendants who plead guilty would in fact have been acquitted had they gone to trial tends to confirm this rational actor model since it suggests such defendants made an "intelligent choice" to trade the chance of acquittal for the certainty of a reduced penalty. ${ }^{99}$

${ }^{95}$ This idea that the "expected punishment cost" to a rational actor is the product of the likelihood of conviction times the expected penalty has been developed at length by cconomists. See Becker, Crime and Punisbment: An Economic Approach, 76 J. Pol. Econ. 164 (1968). Note that it is here assumed that the prosecutor is threatening either mandatory fixed penalty or a range of penalties of which ten years is the mean value. If not, the credibility of the prosecutor's threat becomes an additional factor, i.e., will be the court follow the prosecutor's recommendation?

${ }^{96}$ See note 93 supra.

${ }^{97}$ I do not mean to imply that the offender with a prior record is incapable of being stigmatized, but only that he has already suffered the economic disability that a felony convietion brings. In some cases, the offender may also have become socialized to the subeulture of the professional criminal.

${ }^{38}$ See notc 72 supra.

99 See Finkelstein, A Statistical Analysis of Guilty Plca Practices in the Federal Courts, 89 HARV. L. REV. 293, 298-300 (1975). Such a finding is consistent with the premise that most defendants are risk averters. See Polinsky \& Shavel, note 73 supra. 
Flawed as Bordenkircher's logic thus seems, it cannot be rejected as demonstrably wrong. The fact that defendants plead guilty who would have been acquitted does not in itself mean that the pressures it authorizes are truth distorting. ${ }^{100}$ Nor can one safely conclude that the prosecutor now typically has the power to make the Godfather's offer that cannot be refused. The truth is rather that he sometimes may but generally does not. Bordenkircber is a case involving an aberrational statute, ${ }^{101}$ and thus it tends to give an exaggerated impression of the prosecutor's impact on the sentence. Although the prosecutor can increase the charge, and often the minimum sentence, his sentencing recommendations ordinarily have only a precatory impact. Thus, if the credibility of the prosecutor's threats tends to diminish as he escalates the threatened penalty, the rational defendant will not regard the threat of a long sentence as fully offsetting the low probability of conviction. In other words, the certainty of a one-year sentence following a plea of guilty represents a greater penalty than the threat of a ten-year sentence discounted by a 10 percent chance of conviction. For most defendants, the latter combination will be less severe for several reasons: (1) The defendant will discount the prosecutor's ability to obtain such a sentence from the court. (2) The marginal disutility of incarceration tends in any event to diminish so that for most defendants a ten-year sentence is not ten times the penalty of a one-year term. ${ }^{102}$ (3) The stigmatization component of the penalty establishes a high fixed cost to conviction which is relatively constant whatever the sentence and thus is beyond the prosecutor's power to enhance or reduce. ${ }^{103}$

Thus, it is difficult to reach a bottom-line evaluation of Bordenkircher's implicit assertion that plea bargaining produces in the

${ }^{100}$ On an a priori basis, one cannot say whether the guilty pleas it produces were made by factually innocent defendants or, even if they were, whether such "false positives" are in excess of the "false negatives" (i.e., erroneous acquittals) produced by requirement at trial of proof beyond a reasonable doubt. All that can be said is that Bordenkircber does skew results toward guilt determinations.

${ }^{101}$ Ky. Rev. Stat. $\$ 431.190$ (repealed 1975). Such mandatory enhanced sentences for recidivist offenders have long been opposed by the ABA Standards. See ABA Standards 18-2.1(e), 18-2.2(c), and 18-5.4.

102 See Coffee, Corporate Crime and Punishment: A Non-Cbicago View of the Economics of Criminal Santtions, 17 A.C.L.R. 419, 431-33 (1980).

${ }^{103}$ If the conviction standing alone represents the bulk of the injury to the middle-class offender (sce note 93 supra), then the prosecutor's ability to manipulate the sentence will have only a modest impact on such an offender's assessment of whether to plead guilty. 
aggregate a reliable substitute for trial determinations of guilt. On the one hand, threats do tilt results in favor of guilt determinations, but, on the other, threats probably work best against those having a poor chance of acquittal. Thus, substantial congruence between the two modes of determining guilt (e.g., trials and pleas) is certainly possible. So long as the credibility of the prosecutor's threat declines as he seeks to increase the penalty, the prosecution can sometimes, but not always, compensate for a weak case by threatening a higher penalty. ${ }^{104}$

Of course, defendants are not convicted in the aggregate but in individual cases. From this micro perspective, it is an important fact that prosecutorial threats rise, not in the smooth continuous pattern that model builders tend to assume, but rather in a series of discrete leaps that basically correspond to the mandatory minimum sentences for different charges. Similarly, the credibility of the prosecutor's threat does not decline in any neat symmetrical way that causes it automatically to offset the effect of the increase in the threatened penalty. Thus, there are inevitable kinks in the curve, and this means that extreme pressure can be brought to bear against at least some ill-fated defendants. ${ }^{105}$

This ambivalent evaluation of Bordenkircher is not intended to justify it as a wise or just decision ${ }^{106}$ but to set the stage for a basic contrast: other kinds of bargaining are more likely to be either truth distorting or unreliable substitutes for trial than is the basic pattern faced by the Court in Bordenkircher. For example, judicial involvement in plea bargaining has such a potential because once

104 Logically, the prosecutor can attempt to overcompensate if he realizes that the credibility of his threats diminishes as he escalates them. But here, he runs up against statutory ceilings and obvious judicial resistance. Paradoxically, it may be easier to overcompensate the less culpable the offender is. For example, if the prosecutor thinks a one-year sentence is deserved in the case of a youthful offender and the odds are fifty-fifty on conviction, he can threaten to recommend a two-year sentence if the defendant does not plead guilty. The defendant, however, may doubt that the court will impose exactly the sentence the prosecutor recommends and may therefore expect a one-year sentence on conviction and so decide to go to trial. In turn, however, the prosecutor may seek to overcompensate by threatening a five-ycar sentence. Now the defendant may discount this threat into a likely three-year sentence and plead guilty.

105 The case of John Spinkellink, executed by the State of Florida in 1979, should serve as a reminder. The prosecutor apparently offered Spinkellink a plea bargain under which he would have escaped the death penalty had he pled guilty. See Spinkellink v. Wainwright, 578 F.2d 582, 608-09 (5th Cir. 1978).

106 Truth distortion is, of course, not the only concern of the Due Process Clause. See text infra, at notes 194-98. 
the judge begins to discuss the possibility of a plea bargain with defense counsel, the odds on conviction tend to increase as a direct result. Either the judge may grow irritated with the "unreasonable" bargain requested by defense counsel or with "unreasonable" resistance of the defendant to his counteroffer or, at the least, the court will know of the defendant's willingness to admit guilt on some basis. ${ }^{107}$ Whatever the reasons, the court will then be able to affect the outcome in ways that are unavailable to the prosecutor.

Subsequent to Bordenkircher, two Supreme Court decisions are relevant to this question whether a contextual limitation can be placed on that case. In Corbitt, ${ }^{108}$ the Court again faced a Jacksontype case but this time affirmed the statutory scheme. The New Jersey statute made life imprisonment mandatory for defendants convicted by a jury of first-degree murder but placed a thirty-year maximum on the sentence for second-degree murder. If, however, the defendant pleaded non vult (to the first-degree charge), the judge had discretion to impose the life sentence for first-degree murder or some lesser sentence for second degree. ${ }^{109}$ Two differences distinguish Corbitt from Jackson. (1) The death penalty was not involved in Corbitt. (2) By pleading guilty, the defendant did not automatically escape the maximum sentence but only obtained the possibility of a lesser sentence. In this sense, the chill was less frosty in Corbitt than in Jackson because the disparity was less pronounced between the two sets of penalty ranges applicable to convictions after trial and pleas. Exploiting this modest opportunity to distinguish Jackson rather than overrule it, the Court drew an uncertain line between the two cases. Mr. Justice White's opinion repeatedly emphasized "that the pressure to forego trial and to plead to the charge in this case are not what they were in Jackson"110 and did not exert "such a powerful influence to coerce inaccurate pleas." 11 Admittedly, this argument may have been emphasized simply be-

${ }^{107}$ In some states, the court is permitted to participate in the bargaining process. Sec Flores v. Estelle, 578 F.2d 80, 85 (5th Cir. 1978), cert. denied, 440 U.S. 923 (1979). Contra: United States ex rel. Elksnis v. Gilligan, 256 F. Supp. 244, 254-55 (S.D.N.Y. 1966). Sec also text infra, at note $13 \mathrm{I}$.

108439 U.S. 212.

109 See 2A N.J. Stat. Ann. §§ 113-3 and 113-4 (West 1969) (repealed 1978). The statutory structure is explained in detail in Seidman, note 76 supra, at 479 n.265.

110439 U.S. at 217. See also id. at 226-28 (Stewart, J., concurring).

111 Id. at 225 . 
cause it was fortuitously available, but it does show a shift in focus which could prove important. In Bordenkircher, the focus is on the fair warning; in Corbitt, it shifts to the "powerfulness" of the pressure.

The Corbitt focus could restrict Bordenkircher's logic to areas where the defendant seems relatively able to resist pressure. Any attempt to place such a contextual gloss on Bordenkircher, however, is clouded by Trammel $v$. United States. ${ }^{112}$ Trammel's holding is that one spouse may testify against the wishes of the other at the latter's criminal trial. But, in accepting adverse spousal testimony, the Court buried a time bomb in the final paragraph of that decision. Inducing the wife to testify against her husband by a promise of leniency, it said, does not make the wife's testimony involuntary. ${ }^{113}$ In support of this conclusion, the Chief Justice cited Bordenkircher. One could quibble with this assertion on a variety of grounds: the voluntariness of a witness's testimony does not logically need to be judged by the same standard as that of a plea of guilty. In the former case, our concern is less with fairness to the witness than it is with the reliability of the evidence. But the critical fact about Trammel is that it appears to authorize the use of coercion outside the context of pressure directed at a plea of guilty. Thus, if the Brady/Bordenkircher line of cases are seen as an exception to the general doctrine of unconstitutional conditions, ${ }^{114}$ Trammel may extend this exception beyond the use of pressure to secure a guilty plea and authorize its use to compel the waiver of other rights. Such a result seems ill considered and ignores the differing purposes of constitutional rights. While the rights to trial and to proof beyond a reasonable doubt are basically intended to protect the factually innocent, the privilege against self-incrimination also is intended to protect the factually guilty. Thus, although the assertion in Bordenkircher and Brady that guilty pleas are an accurate proxy for the results of a trial is reasonably related to the purposes of the constitutional protections surrounding the determination of guilt, it has

\footnotetext{
112100 S. Ct. 906 (1980).
}

113 Id. at 914.

${ }^{114}$ Brady, 397 U.S. 742, and Bordenkircber both seem to permit pressure on the defendant because they doubt that it will be truth distorting, given their assumption that pleas of guilty are an accurate proxy for the result of a trial. But such an assumption is irrelevant to the purpose of the Fifth Amendment privilege, which is, of course, intended to protect the guilty as well as the innocent. In addition, the nonutilitarian values associated with the privilege against self-incrimination are stronger, and thus the potential for truth distortion is not as dispositive a test in this area. 
little logical relationship to the purposes underlying the Fifth Amendment, which include sheltering the defendant from torture and the self-degradation involved in forced self-condemnation. ${ }^{115}$

To be sure, this analysis may overread Trammel's brief remark, and distinctions can be drawn. ${ }^{116}$ But clearly the shadow of Bordenkircher is lengthening, and Trammel's use of a bargaining rationale instead of the rehabilitative rhetoric of Roberts shows this trend to be accelerating.

One other basic contrast arises from my analysis to this point. Based on the "powerfulness" of the pressure based on Corbitt's attempted distinction of Jackson, ${ }^{117}$ bargaining for cooperation looks worse than bargaining for a plea of guilty. The prosecutor who wants cooperation is more likely to maximize the pressure on the defendant by overcharging than is the prosecutor who simply wants the defendant to plead guilty. The first prosecutor sees an opportunity to get two birds with one stone (and one of them a much bigger bird than the defendant). In contrast, if our concern is less with the amount of pressure placed on the defendant and more with its potential for truth distortion, then the opposite result can follow, at least in some circumstances. Because the prosecutor is demanding more of the defendant (and possibly exposing him to life-threatening risks), the defendant will have a reduced incentive to plead guilty. In short, while the prosecutor may be raising the expected punishment following a conviction at trial, he is also inherently raising the cost to the defendant of pleading guilty when cooperation is made the price of a plea. The more the prosecutor wants, the closer the scales come to being in balance between these two costs. The rational defendant will focus on the margin between them, and, to the extent it is narrowed, he is more likely to respond by refusing to plead gailty even though the total pressure has been intensified.

Which test is more important? Can we respond to both? This is where the legal theory chosen makes a difference.

\footnotetext{
115 See note 26 infra.

${ }^{116} \mathrm{Mrs}$. Trammel was given use immunity and hence could not incriminate herself. Thus, she did not technically have the privilege available to her and could have been found in civil contempt if she failed to testify. Nevertheless, the broad statement in Trammel that the prosecutor may employ his charging discretion to obtain testimonial cooperation is not clearly limited to cases where the privilege is inapplicable.

117 See text supra, at notes $109-11$.
} 


\section{THE REHABILITATIVE FAST SHUFFLE}

It is hard to find a serious scholar who today maintains that the criminal justice system can intelligently distinguish at any stage among offenders on the basis of their rehabilitative potential. ${ }^{118}$ The empirical evidence is overwhelmingly negative, and the United States Parole Commission some years ago abandoned the attempt to identify the "magic moment" when rehabilitation has been achieved by offenders subject to its jursidiction. ${ }^{119}$ Yet, in recent years, the Court has made increasing use of the concept of rehabilitation, falling back on it when other arguments simply would not work. Thus, in the Death Penalty Cases and in its Eighth Amendment decision last Term, rehabilitation was used to explain why death was different. ${ }^{120}$ In Grayson ${ }^{121}$ rehabilitation was used to explain why a sentencing court could determine that a defendant on trial for one crime was also guilty of another uncharged crime: the court needed wide discretion to appraise "the convicted defendant's potential, or lack of potential for rehabilitation." In Moody $v$. Daggett, ${ }^{122}$ the Court used this same argument to deny a parolee a speedy revocation hearing. In Greenboltz v. Nebraska Penal Inmates, ${ }^{123}$ the subjective character of the rehabilitatively oriented parole release decision was stressed by the majority as a principal reason for holding due process safeguards inapplicable to most

${ }^{218}$ For a review of the empirical evidence, see Lipton, MARTINSON \& WILKS, THE EFfectiveness of Correctional TreatMent: A SURVey of TreatMent Evaluation STUDIES (1975). Professor Martinson did ultimately qualify his initial pessimistic estimate, but only marginally. See Martinson, New Findings, New Views: A Note of Caution regarding Sentencing Reform, 7 HOFSTRA L. REV. 243 (1979).

Recent model statutes and standards have uniformly rejected rehabilitation as a standard by which to measure the length or use of incarceration. See ABA Standards, Standard 18-3.2(a) (v); NATIONAL CONFERENCE OF COMMISSIONERS ON UNIForM STATE LAwS, Model Sentencing and Corrections ACt, Prefatory Note to Article 3; Twentieth Century Task Force on Criminal Sentencing, Fair and Certain Punishment (1976); VON HIRSCH, DOING JUSTICE (1976); AMERICAN FRIENDS SERVICE COMMITTEE, Struggle for Justice (1971); Fogel, ". . . We ARE THe Living ProOF . . .": THe JUSTICE MODEL FOR CORRECTIONS (1975).

119 The United States Parole Commission now employs a guideline system which utilizes actuarially validated factors existing at the moment of sentencing. See 18 U.S.C. §§ 4201-18. For a review, see Coffee, note 29 supra.

${ }^{120}$ Furman v. Georgia, 408 U.S. 238, 306 (1972) (the death penalty "is unique in its rejection of rehabilitation of the convict as a basic purpose of criminal justice"); Rummel, 100 $\mathrm{S}$. $\mathrm{Ct}$. at 1138 (upholding mandatory maximum life sentence under recidivist statute for $\$ 120.75$ theft offense).

121438 U.S. at 48. 122429 U.S. 78 (1976).

123442 U.S. 1 (1979). 
parole hearings. In each case, once the Court starts on its rehabilitation melody, the rest of its opinion is as predictable as what follows when the Marine Corps Band strikes up the first notes of "Hail to the Chief."

Thus, it is not surprising that Roberts never addressed the Blackledge/Bordenkircher inconsistencies but instead solemnly proclaimed: ${ }^{124}$

By declining to cooperate, petitioner rejected an "obligatio[n] of community life" that should be recognized before rehabilitation can begin. . . . Few facts available to a sentencing judge are more relevant to "the likelihood that [a defendant] will transgress no more, the hope that he may respond to a rehabilitative effort to assist with a lawful future career, [and] the degree to which he does or does not deem himself at war with his society."

It strains credulity to believe that the Supreme Court literally means what it here appears to be saying, that heroin dealers who cooperate are good risks who may turn into law-abiding citizens while those who remain silent will not. At times, the Court has virtually admitted that it does not really place much weight on its own rationale. For example, in Grayson the Court stressed the rehabilitative rhetoric in the text but then conceded in footnotes that the evidence now discounted the efficacy of rehabilitative programs. ${ }^{125}$

What then accounts for the anachronistic attachment of the Court to the rehabilitative mode of discourse? A likely answer is that the rehabilitative rationale has several important properties not duplicated by any other model. First, it permits the Court to outflank the doctrine of unconstitutional conditions: awarding sentencing credit to defendants because they cooperate logically implicates this doctrine, particularly after the Court has now said in Roberts that principled distinctions are lacking by which to distinguish inducements from penalties. Using noncooperation as a diagnostic symptom, however, evades this tangled body of law and instead draws on the traditional parens patriae power of the state. Second, analogizing the judge to a diagnostician permits him to question and implicitly warn the defendant of the dangers of non-

\footnotetext{
124100 S. Ct. at 1363.

${ }^{125} 438$ U.S. at 47 n.6 ("Increasingly, there are doubts concerning the validity of earlier, uncritical acceptance of the rehabilitation model") and 47 n.7.
} 
cooperation without appearing to sacrifice his impartiality. ${ }^{\mathbf{1 2 6}}$ Third, the rehabilitative rationale gives a coherent explanation of why the fear of retaliation should excuse noncooperation: because the silence of a frightened defendant is not probative of his potential for rehabilitation. This is an important attribute of the model because fear does not excuse the ordinary citizen who could be subpoenaed and would have no immunity from a contempt charge if he refused to testify on such a ground. ${ }^{127}$ Given the greater exposure of the defendant at sentencing, however, it is a humane and instinctively appealing result to preclude such a reprisal by the state where fear is the motivating factor. Not only is this result most easily rationalized under the rehabilitative model, but under a Bordenkircher rationale exactly the opposite result is reached: the greater the defendant's fear of cooperation, the more justified the prosecutor in threatening him until the balance of advantage for the defendant tips toward cooperation.

Nonetheless, however useful a legal fiction the rehabilitative rationale might be, the happy world it creates for prosecutors is now an unstable one. Near-universal disenchantment exists with the criterion of rehabilitation as a basis for obtaining the length of confinement. Not only have all recent model codes and study groups rejected it, ${ }^{128}$ but recently some state legislatures have done so as well. ${ }^{129}$ Moreover, the pending Federal Criminal Code, which continues to wind a glacial path toward adoption, appears to reject gearing the length of confinement to the defendant's rehabilitative needs. ${ }^{130}$ As a result, the Roberts rationale probably faces an early obsolescence once, as now seems likely, Congress instructs federal courts that rehabilitation and sentencing do not mix.

\section{AN INITIAL SUMMARY}

The forgoing survey should reveal that the scope of Bordenkircher's legitimization of coercion is still very uncertain. For the

\footnotetext{
${ }^{128}$ See note 7 supra.

${ }^{127}$ See Piemonte v. United States, 367 U.S. 556, 559 n.2 (1961) (noting that fear of reprisal cannot justify a refusal to testify before grand jury).

${ }^{128}$ See note 118 supra.

${ }^{129}$ See, e.g., Cal. Penal Code $\$ 1170$ et seq. (West Supp. 1977); Me. Rev. Stat. title 17-A, \$§ 1253-54 (Pamphlet 1977); Ind. Code Ann., § 35-50-2-4 et seq. (Burns Supp. 1977).

130 See Criminal Code Reform Act of 1977, Report of the U.S. Senate Committee on the Judiciary to Accompany S. 1437, 95th Cong., 1st sess. 891-92 (1977). The current
} 
practical lawyer, the current state of the law on coercion (outside the Fifth Amendment context) can be loosely summarized as follows: The prosecutor may "threaten" but not "retaliate," while the judge may "retaliate" but not "threaten."

Spelled out in more detail, this means that under Bordenkircher's gloss on Blackledge the prosecutor may not penalize without a prior warning and an offer to strike a deal, but the court may do exactly this under Grayson's and Robert's expanded notion of rehabilitative diagnosis. Precisely what the Court cannot do is offer a deal because case law has generally precluded overt judicial participation in plea bargaining. ${ }^{131}$ But after Corbitt, the threat can seemingly be structured into the legal system in the form of either a statute or a sentencing guideline which gives a concession for a plea of guilty. ${ }^{132}$

The net effect is that because the limits on the judge do not apply to the prosecutor, and vice versa, they can reciprocally accomplish what neither can do alone. To be sure, judges and prosecutors do not ordinarily act in such hand-in-glove fashion, but, when they wish to, there is little in our current system that prevents them from acting, like Jack Spratt and his wife, to wipe the docket clean.

None of this will come as news to George Higgins or to most experienced criminal law practitioners. The principles latent in Pearce and Blackledge which seemed ready a decade ago to ripen into a comprehensive rule against chilling the rights of criminal defendants never matured or even seriously affected the "real world."133

House bill instructs the courts not to "consider the defendant's need for correctional treatment as a justification for imposing a term of imprisonment or in determining the length of a term of imprisonment." H.R. 6915, § 3703(b), 96th Cong., 1st sess. (1979).

${ }^{131}$ See United States v. Werker, 535 F.2d 198 (2d Cir. 1976). Cases have divided on whether there is a constitutional limitation on judicial involvement. See note 107 stpra. Undoubtedly, the judge can today make veiled threats (sce note 7 supra), but overt participation in the form of a judicially initiated offer to the defendant seems unlikely to pass constitutional muster. Recent empirical evidence suggests, however, that the extent of judicial participation in plea bargaining is more pervasive than is generally realized. See Ryan \& Alfini, Trial Judges' Participation in Plea Bargaining: An Empirical Perspective, 13 LAW \& SoclETY REV. 479 (1979).

${ }^{132}$ But see Mr. Justice Stewart's concurring opinion. 439 U.S. at 227. Corbitt does not authorize an unlimited degree of pressure on the defendant. Because sentencing guidelines are presumptive in effect and do not madate a credit, however, they can be closely anlogized to the statutory structure in Corbitt. Alternatively, the guidelines might overlap (as did the statutory ranges in Corbitt) so that a cooperating defendant gains only the possibility of a more lenient sentence. This, however, seems undesirable on the policy level because it makes the value of the bargain somewhat illusory to the defendant.

${ }^{133}$ Even prior to Bordenkircber, some Courts of Appeals emasculated Blackledge by drawing a distinction between prohibited "substitution of charges" by the prosecutor and permitted 
In part, their stillbirth is attributable to the Court's doubts that plea bargaining could be dispensed with. But at least as responsible has probably been the Court's skepticism, candidly expressed in several cases, that meaningful standards can be developed to control discretionary charging and sentencing decisions. ${ }^{134}$ In this light, Pearce and Blackledge were the exceptional cases in which a prophylactic rule could be easily fashioned because the coercion was objectively measurable. ${ }^{135}$ Although Bordenkircher also presented such an opportunity (the lower court had in fact distinguished initial charging discretion from reindictment and prohibited the latter), ${ }^{136}$ the Court doubted that the game was worth the candle since the prosecutor could have as easily indicted the defendant as a habitual offender in the first instance and then bargained this charge away. ${ }^{137}$

If this analysis is correct that the apparent lack of manageable standards explains in considerable part the Court's failure to have followed up on Pearce, then models cannot be intelligently evaluated apart from the problem of implementation.

\section{Models for Reform: Of Deals, Duress, And Dignity}

Before discussing remedies, I would clarify the different contexts of the Fifth Amendment and the Due Process Clause. Although they overlap, the coverage of the latter is far broader. Consider, for example, the following illustrations:

1. The defendant waives his privilege by testifying. Can the state now compel him to provide testimonial assistance at sentencing which may implicate him in other crimes?

\footnotetext{
"addition of charges." See Hardwick v. Doolittle, 558 F.2d 292 (5th Cir. 1977); Jackson v. Walker, 585 F.2d 189; United States v. Andrews, 612 F.2d 235. Other decisions have restrictively interpreted Blackledge's triggering concept of "upping the ante" by finding that not all changes in position by the prosecutor constituted a raise in the "ante." See State v. Novosel, 27 Cr. L. 2110 (N.H. Sup. Ct. 3/13/80). But see United States v. D'Alo, 27 Cr. L. 2105 (D.R.I. 3/20/80).

${ }^{134}$ This theme is perhaps clearest in Grayson, when the Court notes that the "efficacy of Grayson's suggested 'exclusionary rule' is open to serious doubt" because "[n]o rule of law, even one garbed in constitutional terms, can prevent improper use of firsthand observations of perjury." 438 U.S. at 54 . Bordenkircber sounds a similar note. See text infra, at note 137.

${ }^{135}$ In both Pearce and Blackledge, the Court had the original sentence and an indictment, respectively, to fall back upon.

${ }^{130}$ See Hayes v. Cowan, 547 F.2d 42, 44-45 (6th Cir. 1976).

137434 U.S. at 361.
} 
2. The court requests the defendant to cooperate by serving as an undercover agent. No incriminating testimonial compulsion is involved.

3. Use immunity is given but the defendant responds that if he testifies he will be murdered.

4. The state legislature or a sentencing commission adopts a presumptive sentencing scheme which halves the presumptive sentence in the case of the defendant who pleads guilty. ${ }^{138}$

In none of the forgoing cases is the substantive right against self-incrimination guaranteed by the Fifth Amendment involved. Rather, the defendant's interest is in a procedure that is not truth distorting or otherwise offensive to constitutional values dealing with the process rather than the substantive right.

This section follows this distinction between substantive and procedural rights. First, I shall examine the Fifth Amendment context and consider the implications of Baxter and Roberts. Then I shall turn to the considerably more difficult context of coercion in general, where a clear substantive right is not involved. Three paths will be taken into this thicket.

The best-marked and most traveled route involves the traditional art of the common-law lawyer: drawing distinctions based on the facts and dicta of the decided major cases. In particular, Bordenkircher invites such an effort. But both Bordenkircher and, more recently, Rummel ${ }^{139}$ signal that the Court will not become involved in subjective attempts to measure the degree of pressure in individual cases. Thus, the search must be for tests that allow the Court to stay off what it plainly sees as a slippery slope.

A second approach is to seek a general principle to which the Court is clearly committed and from which can be deduced restrictions applicable to this context. Here the due process calculus announced by the Court is Matbews, ${ }^{140}$ which offers a promising avenue by which to develop limitations particularly with respect to the sentencing judge.

Finally, the naked problem of coercion remains. When a recognized constitutional right is not involved and the risk of truth dis-

138 See note 132 supra.

$139100 \mathrm{~S}$. Ct. 1 [33 (claim that prison term was disproportionate held not justiciable under Eighth Amendment).

140424 U.S. 319. 
tortion does not seem great, are there any limits? For example, suppose now the choice is between turning undercover agent at extreme personal risk and a life sentence? To deal with these issues, it appears necessary to fall back on a last line of defense: "dignitary" or "intrinsic" theories of due process. Although such theories have been recently articulated by respected constitutional theorists, they have not yet received significant judicial acceptance nor is their implementation a simple matter. But such a theory may have other uses. Even if it cannot impose negative limits by itself, it may be able to provide affirmative support for policy proposals which are capable of implementation but which otherwise might not pass constitutional muster. Thus, a natural continuity exists between an examination of such a model and my concern in the final section of this article with the problems of practical reform.

\section{A. BURDENS ON THE FIFTH: THE OPTIONS UNDER}

\section{BAXTER V. PALMIGIANO}

Roberts never examined closely the nature of the defendant's Fifth Amendment rights at sentencing. When one does so, two problems quickly appear. First, in Reina $v$. United States, ${ }^{141}$ the Court acknowledged the continuing validity of the ancient rule that conviction destroys the privilege. This rule is premised on the assumption that after conviction the defendant will be protected by the Double Jeopardy Clause and so needs no further protection against self-incrimination. ${ }^{142}$ Obviously, this premise is shaky. A convicted defendant needs immediate protection at sentencing; in addition, he may still be prosecuted in other jurisdictions because of the same transaction; finally, the events disclosed and acknowledged are likely to make possible a prosecution in the same jurisdiction on another charge whose elements are sufficiently distinct so that the Double Jeopardy Clause will not apply. ${ }^{143}$ As a result,

\footnotetext{
141364 U.S. 507, 513 (1960).

${ }^{142}$ See Brown v. Walker, 161 U.S. 591, 597-600 (1896).

${ }^{143}$ Multiple prosecutions are constitutionally possible based on the same or related conduct where different offenses are involved which do not require precisely the "same evidence" to support each conviction. Under the hypertechnical Blockburger rule, the state need only be required to prove "one additional fact" in order that the two offenses not be deemed to require the "same evidence." See Blockburger v. United States, 284 U.S. 299, 304 (1932); Gore v. United States, 357 U.S. 386 (1958). See Westen \& Drubel, Tozward a General Tbeory of Double Jeopardy, 1978 SUPREME COURT REVIEW 81.
} 
unless Reina is to be closely confined, the defendant may be faced with potential sanctions at sentencing far greater than in Garrity $v$. New Jersey.

Second, as noted earlier, Baxter's ${ }^{144}$ logic suggests that a court may be able to penalize the assertion of the privilege at sentencing. In permitting an adverse inference to be drawn from the prisoner's silence at a prison disciplinary hearing, the Court distinguished cases such as Garrity essentially on two grounds. (1) There was no automatic penalty on the exercise of the right, i.e., no statute required instant dismissal or some similar sanction. (2) The prisoner's silence was only one factor in determining the infraction and could not alone support an adverse finding. ${ }^{145}$

Whatever one thinks of this analysis, it could be stretched to reach the sentencing context. (1) No fixed penalty is placed on the defendant's silence. Indeed, a judge who is an artful practitioner of the game will let the defendant imagine the penalty but will never spell it out. (2) The chief determinant of the sentence will still be the crime and the offender's prior record. To be sure, sentencing is very different from a prison disciplinary hearing. The penalty imposed by the judge for silence is potentially vastly greater. In this light, the real distinction between Garrity and Baxter is the line between what the court perceives (rightly or wrongly) as little burdens and "grave" ones. ${ }^{146}$ Today the sentencing context probably falls on the Garrity side of the line, but it is not clear that it must remain there.

But I need not leave it there. Thus, the interesting implication of Baxter is that if a sentencing guideline system could be implemented which permitted no more than a modest penalty for silence in response to a request to cooperate, then the adverse inference which the court could take begins to look more and more like that in Baxter. Two obvious routes exist to this end. First, if the Court can be convinced that use immunity must be given to requested testimony at sentencing, then a judicial sentencing penalty seems appropriate for a refusal to testify under immunity because it is in the nature of a civil contempt sanction. ${ }^{147}$

\footnotetext{
144425 U.S. 308.

$145 \mathrm{Id}$. at $317-19$.

${ }^{146}$ Cunningbam, 431 U.S. 801, uses the phrase "grave consequence" in determining what burdens are impermissible. See also Berger, note 5 supra, at 276.

${ }^{147}$ Under current law, the maximum civil penalty for a refusal to testify is eighteen months. But the duration of this penalty may not exceed the life of the court proceedings or
} 
Alternatively, if the Court declines to attach automatic use immunity to the sentencing context, it still could extend the Baxter precedent to apply where the penalty for noncooperation is no greater than that administered in Baxter. Of course, this latter route leaves the defendant exposed to additional prosecution and will predictably result in the penalty for silence being imposed.

Still a third rationale exists: Baxter suggests that slight burdens on the privilege will be tolerated where they "involve the correctional process and important state interests other than conviction for crime." 48 An adverse inference as in Baxter is a fortoriori, a stronger burden on the privilege than simply granting leniency to other defendants who do cooperate. Although the majority in Roberts doubted that a principled line is possible, a practical distinction can be drawn between enhancements of sentence and leniency. Where a sentencing guideline system is employed, it would typically prescribe a presumptive range for given combinations of offense and offender characteristics. In addition, it could then give a presumptive credit to be subtracted from this range where significant assistance was given by the offender. Since for the majority of defendants the issue of cooperation never arises, it is unlikely that the sentencing commission would escalate the guideline range applicable to all defendants simply to induce a minority of them to cooperate. Thus, the credit would be very likely a real diminution rather than simply the subtraction of a disguised enhancement.

Indeed, it is arguable that there is a principled distinction here. A distinction can be made between a context that is binary and one that is essentially tripartite. The defendant facing the plea/trial decision is facing an essentially either/or decision, and in this binary context, a credit and a penalty are too reciprocally related to pretend that crediting one who pleads guilty is not equivalent to penalizing him for going to trial. The "cooperation" context, however, subdivides into three categories: some defendants cooperate, some do not, most never have to face the issue for any of

the term of the jury, whichever is shorter. See 28 U.S.C. $\$ 1826($ a). No statutory limit exists on the maximum sentence for criminal contempt. See 18 U.S.C. \& 401 . But an analogy should not be made to a penalty that requires a criminal conviction as a precondition. Case law has also imposed a judicial rule of reason on criminal contempt penalties reducing them generally to terms of not more than two years. See United States v. Leyva, 513 F.2d 774, 779 (5th Cir. 1975); United States v. Gomez, 553 F.2d 958, 959 (5th Cir. 1977).

148425 U.S. at 319. 
a variety of reasons. ${ }^{149}$ In this light, it might be said that to reward a defendant who cooperates is not to penalize another who resists, because the latter defendant is still treated in the same manner as the broader class of defendants for whom the issue never arises.

In short, the answer depends on the angle of vision. From a close-up perspective, the disparity in treatment is between the defendant who cooperates and the one who does not. But a step back increases our depth of vision, and we see the much larger class within which those who resist cooperation may be effectively included. An "offer" then is not a "threat" when declining the offer leaves one no worse off than the "normal" defendant. ${ }^{150}$

By any of the three approaches, a difference in treatment can be rationalized. As a matter of administrative cost and convenience, it makes sense to implement this difference in the form of a credit for those who do cooperate rather than a penalty for those who do not. After all, prisons cost money, and this fact plus preference for minimizing the use of incarceration should lead us to reduce rather than enhance. The maximum ceiling on such credits should be limited by the statutory ceiling on civil contempt.

But one additional protection remains critical. The defendant at sentencing is caught between Scylla and Charybdis. He fears both that the court will penalize him at sentencing if he does not cooperate and that it will see him as a hardened recidivist if he does reveal information that shows him to have had an active criminal past. All defendants would like to appear at sentencing to be facing their first unfortunate encounter with the law. They may not be entitled to this appearance, but they are entitled to more than use immunity which alone does not protect them from the possibility of reprisal at sentencing. Thus, a prophylactic rule seems appropriate. Although the prosecution may inform the court when significant assistance is received from the defendant, neitber the absence of cooperation nor the substance of

\footnotetext{
149 For example, the authorities may already know who the other perpetrators are, or may have caught all of them "red-handed," or the individual defendant may have obviously acted alone.

${ }^{150}$ Such a perspective might also be employed in the veterans' preference cases. See Personnel Administrator of Massachusetts v. Feeney, 442 U.S. 256 (1979). That is, although the Court there used a purpose/effect distinction, one could alternatively say that while most veterans are men, most men are not veterans and the treatment of women like the class of nonveteran men is therefore acceptable. Leniency toward veterans is not a penalty on women so long as they are subsumed within the class of nonveterans which includes both sexes. For another perspective that distinguishes offers from threats, see note 70 supra.
} 
any testimony cooperation should be communicated by the prosecutor or sought by the court or its probation staff..$^{151}$ In essence, this rule simply implements the credit/penalty distinction made above. The state realizes its legitimate interests in being able to induce assistance, but the resisting defendant cannot be penalized since he will appear indistinguishable from the great herd of defendants from whom testimonial assistance is not sought.

In this light, the forgoing rule would in effect extend Griffin $v$. California ${ }^{152}$ to the sentencing context. In Griffin, the Court held that the prosecutor could not ask the jury to draw an inference from the defendant's failure to testify, since this burdened the defendant's Fifth Amendment right. At sentencing, a similar burden is involved when the judge can be made aware of the defendant's refusal to inform. Given the availability of less drastic means of realizing the state's interest (e.g., both the forgoing credit approach and civil contempt sanctions once use immunity is conferred), the sentencing process should not be so abused. Concededly, prophylactic rules such as that in Griffin would not be applied in a nonjury trial (at least not as rigidly), where the judge cannot help knowing that the defendant has failed to take the stand. At sentencing, the refusal to inform is information that can and should be denied the sentencing judge. ${ }^{153}$

\section{B. THE CONTRACT MODEL: PROFESSOR WILLISTON MEETS DEFENDANT HAYES}

Bordenkircher's most important statement is probably its assertion that a threat does not amount to retaliation "so long as the accused is free to accept or reject the prosecution's offer." 154 To justify this result, the Court announced its "mutuality of advantage" thesis that such deal making benefited both sides. ${ }^{155}$ In short,

151 This rule would not, however, apply to a damaging admission the defendant gratuitously made at sentencing in order to acquire use immunity and thereby interfere with a planned second prosecution. This can be easily distinguished. See Hutto v. Ross, 429 U.S. 28 (1976).

152380 U.S. 609 (1965).

${ }^{153}$ However, a "blind sentencing" structure could be devised under which the court would not learn whether the defendant had pleaded guilty or gone to trial. Indeed, sucb a system could be combined with a weak sentencing credit, subtracted after the court imposed its initial sentence, in order to provide some mild incentive for pleas of guilty.

154434 U.S. at 363.

15s 1 bid. (citing Brady v. United States, 397 U.S. 742, 752 (1970)). 
the Court has reinterpreted the traditional issue of the "voluntariness" of the plea ${ }^{156}$ by viewing it in contract law terms: so long as some legitimate consideration is received by the party to be bound, then the court will not invalidate a hard bargain simply because one side later decides it was unfair.

If this is all there is to the rationale of Bordenkircher, then presumably the prosecutor could always threaten reindictment or a sentencing appeal since the "mutuality of advantage" criterion is by definition met any time there is the potential for the prosecutor to be more severe or more lenient. Standing alone, this contract analogy would produce an empty theory incapable of drawing boundaries. But a contract theory presupposes the capacity to contract, and this element, present in Bordenkircher's reasoning, offers a potential bulwark by which to contain the case. In its emphasis on the capacity for "intelligent choice" and the limited likelihood of a plea of guilty by the factually innocent, ${ }^{157}$ Bordenkircher seemingly limits its approval of adversarial bargaining to those contexts where the contest is a fair one.

When, then, does a capacity for "intelligent choice" not exist? Several arguments can be made. First consider the case of a prosecutor who informs a defendant that if the latter appeals an adverse bail determination, he will refuse to accept a plea to a lesser included charge. ${ }^{158}$ This case differs materially from that of simple plea bargaining because of the inherent imbalance between the right the defendant is asked to waive and the interest that is threatened to make him do so. Presumably the bail is less important to the defendant than is the sentence, and so he will trade the lesser for the greater. Bordenkircher's assertion that plea bargaining is a process of "give-and-take negotiation" in which both sides "arguably possess relatively equal bargaining power" simply cannot be stretched to apply to this situation. ${ }^{159}$ In sum, the inequality in their respective bargaining positions produces, not fair bargaining,

156 The traditional "black letter" law of sentencing requires that a guilty plea be "voluntarily" and "knowingly" made. See Boykin v. Alabama, 395 U.S. 238 (1969); Henderson v. Morgan, 426 U.S. 637 (1976). This is much-traveled ground, and I leave it to others to plow a new furrow through it.

157434 U.S. at 363.

${ }^{158} \mathrm{Cf}$. Andrews, 613 F.2d 235 , note 70 supra (claim of prosecutorial retaliation for successful appeal by defendant of adverse bail determination). See also note 58 supra.

159434 U.S. at 362 (quoting Parker v. North Carolina, 397 U.S. 790, 809 (1970)). 
but a contract of adhesion. Second, in the reverse case, where bail is denied the defendant and the prosecutor makes an offer under which the sentence would be equal to the time already served, the risk of false self-condemnation is clear. ${ }^{160}$

Another approach is to focus on whether the defendant is in a position to appraise the relative risks intelligently. Bordenkircher emphasizes that the defendant with the assistance of counsel can adequately evaluate the risk of conviction. In contrast, the defendant cannot engage in the same sort of "give-and-take negotiation" once a conviction has been secured. Thus, prosecutorial threats should be impermissible in this postconviction context where the sentencing function has traditionally belonged to the judge rather than the adversaries and where the sentence is not capable of reliable estimation by the defendant. ${ }^{161}$ Similarly, the parties cannot reasonably appraise the risk of revenge against an informant. The defendant may not know whether the person he informs against is a member of organized crime or otherwise has the ability to retaliate. Even if the government assures him that secrecy will be maintained, he still cannot judge the value of this promise. Future events are unknowable. In this light, there is an important confluence here between Roberts's rehabilitative rationale and the argument that the threat of private retaliation impairs the capacity for "intelligent choice" on which Bordenkircher is founded: both approaches can be stretched to reach the intuitively desirable position that the defendant who is in legitimate danger of physical retaliation need not cooperate. The Court, however, is probably committed to its Bordenkircher conclusion that "intelligent choice" is possible with respect to the outcome of the trial, and this assumed reality can be readily distinguished in the sentencing context.

To sum up, the contract theory provides a basis for rejecting a prosecutorial attempt to tie issues (such as bail appeal or a constitutional challenge to the statute) where the defendant has no realistic

\footnotetext{
${ }^{160}$ The appropriate remedy is different for these two cases. The defendant who resists the pressure and is convicted is entitled to a reduced sentence or a new sentencing if the amount of the illegitimate enhancement cannot be determined. The defendant who succumbs may be entitled to withdraw his plea. Realistically, however, such a defendant will be reluctant to do so if he could not be convicted and get a higher sentence. Pearce should preclude such an increased sentence.

${ }^{161}$ Some judges have already suggested such a dividing line. See Andrews, 612 F.2d at 254 ("Bordenkircher presents a case where ... the defendant's ability to choose-eliminated any due process problems") (Keith, J., dissenting). See also Smaltz, note 5 supra.
} 
opportunity to bargain. In addition, the imbalance between the prosecutor and the defendant is too great once a conviction is secured to permit continued bargaining over the sentence in the postconviction area where "give-and-take negotiation" is much less possible. Finally, it is at least arguable that "intelligent choice" is not possible where the defendant's life is in danger (the choice is "Hobson's Choice"). Here the defendant would not have the right to withdraw his plea but should be entitled to a resentencing in which the factor of noncooperation would not be called to a new sentencing judge's attention. ${ }^{162}$

As a model for reform, the contract analogy takes us only partway to a satisfactory position. Under this model, some types of unjustified prosecutorial coercion may still be permitted. For example, if the prosecutor warns the defendant that if he appeals his conviction and obtains a new trial the prosecutor will respond with a higher indictment, ${ }^{163}$ such a threat resembles the warning given in Bordenkircber, because what is essentially being negotiated is guilt and the applicable sanction. Nevertheless, it is undesirable to extend the zone of adversarial combat into this area either because chilling appeals insulates error or because there is less need to rationalize plea bargaining in this context where it is not as important to the efficient administration of criminal justice. Thus the contract model, even if limited to the context of "zero sum" bargaining, does not limit the scope of bargaining to the extent that may be desirable.

There is a more basic inadequacy in the contract model. It does not distinguish between extreme pressure and modest inducement; it ignores the degree of coercion, and focuses only the capacity of the parties to bargain. Of course, this is the attitude that courts have taken with respect to claims of contractual oppression. To threaten, as in Bordenkircher, a life sentence for failure to plead guilty to the charge of uttering a forged check in the amount of $\$ 88.30$ is clearly disproportionate and tends to make the "intelligent choice" that of "false self-condemnation." Once the Court dons the intellectual blinders of contract law, however, and enters a world

${ }^{162}$ See United States v. Robin, 553 F.2d 8, 10 (2d Cir. 1977).

${ }^{163} \mathrm{Cf}$. United States v. McFadyen-Snider, 590 F.2d 654 (6th Cir. 1979) (perjury indictment barred on finding that it would not have been brought had the defendant not appealed successfully in a separate proceeding). This case, however, did not involve the same prior warning as here contemplated. 
where peppercorns have constituted adequate consideration, it is not surprising that it fails to respond to this imbalance. In the last analysis, the greatest deficiency in Bordenkircber's approach is its inability to recognize that at some level prosecutorial pressure ceases simply to induce the defendant to abandon weak defenses but rather becomes truth distorting by forcing him to plead guilty when his case is meritorious. This pressure may be resistible in many cases for reasons already analyzed. ${ }^{164}$ But for many "factually innocent" defendants their prospects for acquittal may turn upon the credibility of witnesses, the interpretation given ambiguous remarks, legal defenses involving the jurisdictional reach of penal statute, or the unpredictable testimony of prosecutorial witnesses (who may in turn be selectively recalling events in order to "cooperate" fully to earn their own concessions). In addition, the existence of mandatory minimum sentences often makes the prosecutor's threat very credible. For such defendants, the requirement of proof beyond a reasonable doubt loses its significance because the balance of advantage it otherwise gives the defendant is offset by the state's ability to escalate the penalty.

\section{THE UTILITARIAN CALCULUS: FOCUSING ON THE RISK OF ERROR}

Bordenkircher, of course, does not apply to the judge, whose impartiality would be compromised by the fair warning to the defendant that its doctrine requires. ${ }^{165}$ As any experienced defense counsel knows, however, judges do use their sentencing power to reward and punish defendants for a variety of acts, e.g., pleading guilty, making restitution, cooperating with the government, acknowledging guilt so as to preclude appeal, etc. But what substitute is available for the standardless discretion that the open-ended rehabilitative model gives the court? Would a sentencing guideline system that gave a credit for a plea of guilty or cooperation with the prosecution be constitutional? While this latter question involves Fifth Amendment issues as well, Baxter suggests that a balancing

\footnotetext{
164 Obviously, that defendant Hayes persisted shows that some defendants will be undeterred and thus confirms the earlier analysis that the defendant may doubt (here incorrectly) the credibility of the prosecutor's threat. But one cannot generalize from the evidence supplied by the reported cases, since the instances in which defendants do succumb to the pressure will generally remain invisible.
}

${ }^{165}$ See Werker, 535 F.2d 198. 
test will also be applied to determine how much of a burden can be placed on that right. Thus, what follows is a balancing model that the Court might consider when it next faces any of the cluster of issues involving the Roberts context.

1. From Mathews v. Eldridge to United States v. Raddatz. In Mathews v. Eldridge, ${ }^{166}$ the Court attempted in 1976 to formulate a comprehensive due process formula for administrative adjudications. Although its formula has been criticized, ${ }^{167}$ the Court has steadfastly stuck to the Mathews test, which requires a court to balance three factors: ${ }^{168}$

First, the private interest that will be affected by the official action; second, the risk of an erroneous deprivation of such interest through the procedures used, and the probable value, if any, of additional or substitute procedural safeguards; and finally, the Government's interest, including the function involved and the fiscal and administrative burdens that the additional or substitute procedural requirement would entail.

To be sure, there is a substantial difference between administrative due process and criminal due process, and tests applicable to the former do not automatically have relevance to the latter. But, in an unnoticed transition of some significance, the Court has recently begun to apply the flexible Mathews formula to criminal due process issues. Citing Matbews in a 1979 decision, Greenboltz v. Nebraska Penal Inmates, ${ }^{169}$ the Court declined to require traditional due process safeguards at parole hearings, because it doubted that those safeguards would substantially minimize the risk of error in what it saw as a subjective decision-making process. If Matbews governs the due process status of parole, it is certainly logical that it should apply as well to sentencing, since in its parole and probation revocation decisions the Court has recognized that these two contexts approach functional equivalence. ${ }^{170}$ In any event, the clearest indication that the Mathews criteria will in the future govern criminal

\footnotetext{
166424 U.S. 319 (1976).

${ }^{167}$ See Mashaw, Tbe Supreme Court's Due Process Calculus for Administrative Adjudication in Matbews v. Eldridge: Three Factors in Search of a Tbeory of Value, 44 U. CHI. L. REv. 28 (1976).

168424 U.S. at 335.

169442 U.S. at 13-14. See also opinion of Marshall, J. dissenting, id. at 32-35.

${ }^{170}$ See Gagnon v. Scarpelli, 411 U.S. 778 (1973) (holding parole revocation standards of Morrissey v. Brewer, 408 U.S. 471 (1972) applicable to probation revocation).
} 
due process decisions came in the 1979 Term in United States $v$. Raddatz. ${ }^{171}$ The question in Raddatz involved the procedures for determining the voluntariness of a confession-an issue having obvious similarities to the voluntariness issue inherent in coercing cooperation. Specifically, could the voluntariness of a confession be determined by the court based only on a magistrate's findings without the trial court rehearing the contested testimony? Although the Court upheld reliance on a magistrate, the more relevant fact here is that both the majority decision, the partially concurring opinion of Mr. Justice Powell, and the dissenting opinion of Mr. Justice Marshall agreed that the government criteria were those set forth in Matberws. ${ }^{172}$ Symptomatically, however, each opinion applied the Matbews formula differently.

Raddatz was not the only case that Term in which the Court used the vocabulary of Matbews. In Beck v. Alabama, ${ }^{173}$ it struck down a death penalty statute which gave the jury no option to find the defendant guilty of a lesser included offense which had the effect of "substantially increasing the risk of error in the fact-finding process." This trend has roots going back at least to the Court's 1975 Term. Since then, the Court's rhetoric in criminal procedure decisions has revealed a preoccupation with the "search for truth" and the truth-destroying properties of exclusionary rules. ${ }^{174}$ In the 1979 Term, this trend culminated in a series of decisions narrowing the standing of criminal defendants to assert Fourth Amendment violations. ${ }^{175}$ In so doing, the Court emphasized the "costly toll" such exclusionary rules had on the "truth finding functions of judge and jury."176

171100 S. Ct. 2406 (1980).

172 Mr. Justice Marshall noted acidly of the Matberws formula: "The Court recites this test, but it does not even attempt to apply it." Id. at 2425. Only Mr. Justice Stewart's dissenting opinion (which interpreted the statute to require a hearing before the judge and so avoided the constitutional issue) failed to acknowledge the applicability of the Matberws formula.

${ }^{173} 100$ S. Ct. 2382, 2387, 2389 (1980).

174 See Seidman, note 76 supra, at 449 n.69. Representative decisions sounding this theme are: Stone v. Powell, 428 U.S. 465, 489-91 (1976); Manson v. Brathwaite, 432 U.S. 98, 112-13 (1977); United States v. Janis, 428 U.S. 433, 448-49 (1976).

175 See, e.g., United States v. Payner, 100 S. Ct. 2441 (1980); United States v. Salvucci, 100 S. Ct. 2547 (1980); Rawlings v. Kentucky, 100 S. Ct. 2556 (1980). These cases, in turn, grew out of a decision the prior term which limited standing to invoke the Fourth Amendment. See Rakas v. Illinois, 439 U.S. 128 (1978).

${ }^{176}$ Payner, 100 U.S. at 2445 (citing Rakas, 439 U.S. at 137-38). 
If the Court is to be evenhanded, this preoccupation with the "risk of error" and the centrality of the "truth finding function" of the criminal process should constrain both the prosecutor and the defendant equally. If this new test means that the defendant may often be unable to assert Fourth Amendment violations, so should it also limit the prosecutor's ability to apply an unlimited degree of pressure to secure cooperation or pleas of guilty. In addition, it should constrain the sentencing court as well, since the primacy of the truth-finding function should require the subordination of rehabilitative goals to the search for factual accuracy. If the risk of an erroneous determination is high, then the state would not be able to justify that risk on the grounds of its claimed benevolent intentparticularly if the defendant is no longer able to justify suppression of much accurate information under the exclusionary rule because of the claimed need for an effective deterrent to police misbehavior.

To say that the Matherws formula can lead to such conclusions is not, however, to claim that the Court will follow its logic this far. Indeed, the disquieting fact about Matherws is that, whenever it is invoked, its flexible formula seems always to permit the Court to uphold the constitutionality of the challenged practice. ${ }^{177}$ Nonetheless, the Mathews formula has one critical advantage: it calls for weighing the quantum of pressure applied and for distinguishing between reasonable inducements and truth-distorting coercion.

2. Applying the calculus: some first derivatives. Of Matbews's three factors, the first is the easiest. A criminal defendant has several interests which are entitled to substantial weight in any constitutional balancing. To begin with, he is entitled to the procedural protections accorded criminal defendants, including most importantly the right to force the state to prove its case beyond a reasonable doubt. ${ }^{178}$ These are in jeopardy if he can be coerced into pleading guilty on a basis that does not accurately reflect the probability of conviction at trial. Second, a series of Supreme Court decisions have held that the offender is entitled to a sentence which is not based on "misinformation of a constitutional magnitude."179

${ }^{177}$ In addition to Mathews itself, see Greenboltz, 442 U.S. 1. See also Mashaw, note 167 supra, at 29 n.4 (noting that plaintiffs had been "uniformly unsuccessful" since Matbews).

${ }^{178}$ See In re Winship, 397 U.S. 358 (1970). To the extent that the prosecutor's escalation of the penalty can compensate for deficiencies in the proof, this right is reduced in its significance.

179 See Townsend v. Burke, 344 U.S. 736 (1948); United States v. Tucker, 404 U.S. 443 (1972); cf. Dorszynski v. United States, 418 U.S. 424, 440-41 (1974). 
Third, the defendant has the basic due process right to a detached, neutral umpire. That necessarily means a sentencing judge who does not become so involved in the bargaining process that he loses his impartiality. ${ }^{180}$ Finally, the defendant has a broad interest in not being subjected to the risk of a reprisal by those against whom he is asked to inform. Admittedly, this interest is a highly qualified one since material witnesses have the same interest when they are detained or required to testify, but at least the ordinary witness can seek to quash the subpoena or require some minimal showing of need or relevance before he may be so exposed.

What is the risk of an erroneous deprivation of these interests? First, the right to the protection of the "reasonable doubt" standard is nullified if the prosecutor can simply escalate the threatened penalty and thereby coerce a guilty plea. Bordenkircher said that this risk of "false self-condemnation" is small. ${ }^{181}$ But it also recognized that other forms of pressure could "skew" the defendant's assessment. ${ }^{182}$ From the vantage point of Matherws, one can see immediately that bargaining which yields a reliable proxy for the trial is more acceptable than that which distorts the results of a litigated outcome. In this light, the increased risk that the prosecutor will overcharge where he seeks cooperation can be introduced into the constitutional calculus.

Other risks exist. The judge may confuse the defendant's fear of private retaliation with an unrepentant, contemptuous attitude toward society. One need not dwell long on the cultural gulf that separates most judges from most defendants, or on the stress the defendant is under at sentencing, to see that this possibility is substantial. Even more important, the judge who actively engaged in offering an inducement or a penalty may resent the defendant's resistance and so (consciously or unconsciously) impose a higher sentence. Compounding this risk is the total absence today of any requirement of findings of fact or a statement of reasons at

${ }^{180}$ The classic statement of this rule is in Tumey v. Ohio, 273 U.S. 510 (1927); see also In re Murchison, 349 U.S. 133 (1955). In Wolff v. McDonnell, 418 U.S. 539 (1974), the Court extended this concept to the correctional stage, ruling that an inmate facing a prison disciplinary hearing was entitled to a disinterested fact finder who had not been a witness to or participated in the disputed matter. Once the judge begins to negotiate a bargain, he is arguably no longer a disinterested party, but rather a participant. See also United States v. Werker, 535 F.2d 198 (2d Cir. 1976).

181434 U.S. at 363.

182 Id. at 364 n.8. 
sentencing. ${ }^{183}$ Candidly put, the only judge who stands in real risk of appellate reversal is the judge who laudably attempts to give such an explanation.

Another source of error applies as well to the defendant who is willing to cooperate. The defendant may simply not process the knowledge that the prosecutor is seeking. "Cooperation" is a notably vague term and seems to give the prosecution considerable latitude in deciding whether the defendant is to be rewarded or punished. ${ }^{184}$ In principle, the defendant is entitled to contest at sentencing any statement made by the prosecution, ${ }^{185}$ but in practice the sentencing colloquy is terse, and the prosecution's statement that the defendant has or has not cooperated is usually definitive. This seeming delegation of authority to the prosecutor to determine the cooperation issue is in sharp contrast to the status of the defendant if the prosecution were required to commence a contempt proceeding against him after it had first granted immunity and failed to receive information it believed the defendant possessed. At sentencing, the prosecution is not required to meet any burden of proof or observe any trial-type standards. ${ }^{186}$

Finally, the error introduced into fact-finding proceedings is not limited to the sentencing proceedings involving the defendant. The typical criminal defendant should not be idealized: those who deal in heroin are probably prepared to commit perjury as well. Thus,

\footnotetext{
183 See note 30 supra.
}

184 This problem can be partly cured by Mr. Justice Brennan's suggestion in Roberts of a mandatory collateral inquiry by the sentencing court. See $100 \mathrm{~S}$. Ct. at 1366 . But there remains the basic problem in many cases that the defendant may not possess the knowledge which the prosecution is convinced it has. It is, for example, not unthinkable that drug dealers could do business on an anonymous or first-name-only basis. Admittedly, the court is entitled to draw inferences once it has heard both sides, but where the liberty of a defendant turns on an inference, it is best that the sentencing concession or penalty be kept modest. See also Fatico, $458 \mathrm{~F}$. Supp. at 409 (high standard of proof required where defendant's liberty interest is imperiled at sentencing).

$185 \mathrm{Ex}$ parte contacts between the court and prosecutor have long been condemned. United States v. Rosner, 485 F.2d 1213 (2d Cir. 1973); Haller v. Robbins, 409 F.2d 857 (1st Cir. 1969). The defendant's right to allocution at sentencing is uniformly recognized. Admittedly, however, information from the prosecutor can reach the court through the undisclosed portions of the presentence report prepared by the probation officer. But the battle to open up the presentence report to the defendant has been largely won. See commentary to ABA Standard 18-5.4.

186 Either a civil proceeding under 28 U.S.C. $\$ 1826($ a) or criminal prosecution under 18 U.S.C. $\$ 401$ would place the burden of proof on the prosecution. In contrast, only a few decisions have placed the burden on the prosecution at a sentencing hearing. See Note, note 15 supra. But see also ABA Standard 18-6.4(c); Fatico, 458 F. Supp. 388. 
they may interpret the prosecutor's request for cooperation as an invitation to fabricate or tailor testimony to the desired end. ${ }^{187}$ At a minimum, the defendant may expect that he has an implied grant of immunity from a prosecution for perjury. The result is that coercion begins to infect independent proceedings. A vicious circle may begin: the factually innocent defendant may plead guilty because he believes that prosecutorial pressure on a convicted key witness is likely to produce perjured testimony. Thus, there is not only the risk of error, but error compounded.

In view of this risk of error, what is the interest of the state in rewarding cooperation? Here it is necessary to consider judicial and prosecutorial pressure separately. When the court seeks to coerce the defendant (either by suspending imposition of the sentence or by indicating its willingness to consider a motion for reduction of the sentence), the state's interest is relatively weak. By definition, the court is a neutral umpire and cannot claim an interest in securing victories for the prosecution or the defense. As Roberts indicates, the only defensible rationale for the sentencing court's inquiry is a diagnostic one. But realistically, the court's ability to use such information intelligently is weak at best and negative at worst. ${ }^{188}$

When coercion is employed by the prosecutor, the analysis is different but the result is not. Prosecutorial pressure does produce testimony that would not be offered gratuitously. In all likelihood, a considerable number of convictions of factually guilty defendants have depended on this technique. But the state's interest can also be realized by less drastic means. The state can prosecute the defendant for civil or criminal contempt if it is willing to grant use immunity. ${ }^{189}$ This may be costly and time consuming, but cost considerations alone can hardly justify outflanking the criminal process, particularly when the burden on the state at civil contempt hearing is relatively modest.

A further element of the Matherws formula is "the probable value, if any, of additional or substitute procedural safeguards." 190 This factor is more troublesome. Recent cases have shown the Court to

187 This possibility was noted by Judge Weinstein in Fatico, 458 F. Supp. 388, citing Marro, Rising Concern over Informers Being Voiced by Legal Officials, N.Y. TiMES, July 23, 1978, p. 1.

${ }^{18 B}$ I have discussed this theme at greater length in Coffee, The Future of Sentencing Reform: Emerging Legal lsues in tbe Individualization of Justice, $73 \mathrm{MICH}$. L. REV. 1361 (1975).

${ }^{189}$ See note 147 supra. 190424 U.S. at 335. 
be skeptical that procedural safeguards would reduce the risk of error. ${ }^{191}$ This skepticism has particular merit in the case of plea bargaining since even if the prosecutor were constitutionally denied the power to reindict because the defendant had refused to cooperate, the prosecutor's original charging discretion would still remain unconfined. ${ }^{192}$ Thus, the prosecutor could overcharge initially, and, if the defendant chose to cooperate, he could then accept a plea to a lesser included offense. In time, the latent threat would be quickly communicated to sophisticated defense counsel. When we turn to the judge, however, procedural safeguards seem more feasible. For example, the following corollary could be added to the prophylactic rule discussed earlier in my analysis of the Fifth Amendment privilege: Altbough the prosecutor may inform the court of any assistance provided by the defendant, refusals to provide nontestimonial assistance sbould stand on the same footing as testimonial refusals and not be communicated to the court by any means. Once again such a rule effectively permits the state to induce assistance but not to "penalize" nonassistance because the noncooperating defendant will be indistinguishable from the broader class of defendants for whom the issue does not arise. Here, however, because the privilege is not applicable to requests that the defendant serve as an undercover agent prospectively, no substantive constitutional right is even arguably chilled by this distinction of leniency from a penalty. Such a proposal does, however, face the obstacle of the Court's much too facile assumption in Trammel that a prosecutor may bargain for assistance under the Bordenkircher rationale. ${ }^{193}$ Still, Trammel should be limited to the prosecutor's charging discretion, and the Matherws model here advanced is mainly applicable to the sentencing court, from which the above proposed rule could still cut off communications about nonassistance.

The Mathews analysis can equally be applied to other problems of judicial pressure on the defendant. For example, a judicial request to the defendant to acknowledge his guilt (and thereby forgo an appeal) carries a substantial risk of error. Just as in plea bargaining, the incentive can be strongest to pressure the defendant when the case against him is weakest. Thus, the hypothetical judge who

\footnotetext{
191 See note 177 supra.

${ }^{192}$ Bordenkircber, of course, made this point expressly. 434 U.S. at 365.

$193100 \mathrm{~S}$. Ct. at 914.
} 
knows that his ruling on a suppression motion is suspect may be particularly eager to chill an appeal by that defendant. In this perspective, such judicial pressure becomes self-insulating and hence truth distorting. The state's interest also seems weaker, since the cost to it of an appeal is likely to be less than that of a trial and appellate clarification of the law may often be in the state's interest.

Distinctions in terms of the quantum of pressure applied can also be justified under a Mathews analysis. An increased threat increases the risk of false self-condemnation. Presumably, too, the state has a far lesser interest in inducing individuals with a probability of acquittal to plead guilty than it does in inducing those with a probability of conviction. If so, then the Mathews balancing formula finds it easier to justify limited pressure than extreme pressure. Admittedly, the Court itself is unlikely to attempt to draw any such lines in individual cases, but this logic can serve to uphold a sentencing guideline system that gives a discount from the normal presumptive term for cooperation.

3. Summary. The Matbews formula, then, does supply a string on which many beads can be strung. While it is consistent with the premise of Bordenkircher that some pressure may produce an accurate discounting of the results of a trial, it can distinguish in terms of the level of pressure and also between the "normal" coercion inherent in plea bargaining and more pathological forms (such as the threat to indict relatives of the defendant). A Matbews-based model seems logically suited for dealing with the judge's role and offers a natural replacement for rehabilitative rhetoric on that eventual day when the Court abandons this simplistic view of sentencing.

What a Matbews model does not do, however, is to preclude the use of prosecutorial threats to induce cooperation. As noted earlier, when the prosecutor seeks more than a plea of guilty, he may actually force the defendant to go to trial. The prosecutor may compensate for this by offering an even greater sentencing discount, but, when he thus raises both what he wants and what he will offer in return, he is simply recreating the zero sum game in a manner which keeps both parties roughly equidistant from the midpoint. This is neither logically truth distorting nor does it undercut the "reasonable doubt" standard.

In contrast, a Matbews approach should justify preventing the court from learning of the defendant's noncooperation. In a system 
of justice geared to truth finding, the court's interest in such information is small in comparison to the defendant's interest, and alternative sanctions are available through the civil contempt penalties where the refusal was not privileged.

\section{THE DIGNITARY MODEL}

Among legal theorists, utilitarian models appear to have fallen into disfavor. ${ }^{194}$ Such models, we are told, fail to recognize the other values subsumed by the Due Process Clause in addition to accurate fact finding, i.e., associational and participative values, human dignity, equality, and personal autonomy. ${ }^{195}$ The writers who have advanced this theme in a stimulating series of works -e.g., Professors Mashaw, ${ }^{196}$ Michelman, ${ }^{197}$ and Tribe ${ }^{198}$ have largely focused on the administrative process rather than the criminal process. How valid is this critique when transposed? Does it produce materially different results?

Proponents of a Dignitary Model typically stress two values that its recognition would shelter and which a purely utilitarian model tends to ignore: revelation and participation. Important as these rights may be, they do not address directly the dilemma of the defendant at sentencing. His problems are more immediate and stark than those of the typical citizen facing the bureaucratic state. Indeed, the court which wants cooperation is generally quite prepared to "reveal" its reasons.

The Dignitary Model's vocabulary, however, contains much more. Central to the model is a desire to preserve and enhance human dignity and autonomy. Amorphous as these values are, there are few, if any, situations as corrosive to them as pressure to inform against a friend or the dilemma that arises when one is compelled to choose between "false self-condemnation" and the indictment of a spouse or relative. If the world of Eddie Coyle

\footnotetext{
194 See Barry, Book Review, 88 YALE L.J. 629, 630-32 (1979).

${ }^{195}$ In addition to the sources next cited, see THIBAUT \& WALKER, Procedural Justice: A Psychological ANalysis (1975), for a discussion of the "process values" in dispute resolution.

196 Mashaw, note 167 supra.

${ }^{197}$ Michelman, Formal and Associational Aims in Procedural Due Process, in XVII NOMOS: Due Process 126, 128 (Pennock \& Chapman, eds. (1979)).

${ }^{198}$ See TrIBE, note 17 supra, at $\$ 10-7$; Tribe, Structural Due Proces, 10 Harv. Civ. RTS.-CIV. LIB. L. REV. 269 (1975).
} 
seems one of unmitigated bleakness, suspicion, and distrust, prosecutorial pressure to inform may have helped to make it so. Thus, the Dignitary Model does supply a distinctive perspective: pressure which is "dehumanizing" offends it, regardless of its impact on the factual accuracy of the proceedings. Indeed, this perspective captures one little-noticed aspect of the problem of coercion to cooperate: it tends to focus on the underling, on the essentially minor figure who is in a position to provide useful testimony. ${ }^{199}$ Thus, whether or not the pressure produces truth distortion, it does distort the penalty structure and produce morally unjustified sentencing disparities.

Potentially, the Dignitary Model offers broad normative theories by which to object to such pressure. First, coercion which seeks the cooperation of the defendant in the prosecution of other cases uses him as a means, rather than an end in himself, and thus inherently offends Kantian theories about the inviolability of the individual. ${ }^{200}$ Such a theory, however, stands little chance of judicial adoption. Second, both egalitarians and "Just Deserts" theorists may object to the equality-distorting impact of sentencing concessions either because the opportunity to receive such concessions is not uniformly available or because such concessions interfere with retributive theories for the allocation of punishment. Again, such theories ask more than the Court can be expected to grant. ${ }^{201}$

In contrast to the ideological rigidity of the Dignitary Model on these issues, it can take a much more flexible and tolerant view of traditional plea bargaining. To subscribe to a "dignitarian" perspective, one must logically start from the premise that individuals have a capacity for free choice and autonomous decision making. It follows that men of free will should be able to choose whether to go to trial or plead guilty. To insist on "protecting" them from any offer of leniency by the prosecutor can be seen as offensively paternalistic. In short, if one starts from a strong premise of free will, then not every chilling effect should be taken seriously, but rather only those that pose basic value conflicts for the prototypical man of free will. Thus, a threat which requires the individual to inform or

199 See note 53 supra.

200 See Nemerson, note 5 supra, at 688-94.

201 With respect to sentencing, the Court has held to a weak "rational basis" test for judging equal protection attacks on sentencing practices. See McGinnis v. Royster, 410 U.S. 263 (1973). 
expose his family to prosecution is very different from one that requires him only to acknowledge guilt or stand firm on his innocence.

But is the Dignitary Model really a model or only a footlocker full of unincorporated constitutional rights which its proponents prefer? A perceptive critic of "intrinsic" or "dignitarian" formulations that attempt to find a value in procedural safeguards independent of their ability to assure accurate fact finding has argued that attempts tend to make disguised assertions of an "inchoate or nascent substantive constitutional right." ${ }^{202}$ Some of this tendency seems visible here. A claim that "process values" or human dignity is offended when individuals are forced to make choices involving a credible threat of physical retaliation arguably translates into the simpler statement that compelling the individual to choose in this manner itself constitutes punishment-indeed, punishment which should be seen as offending the Eighth Amendment's proscription. Such choices can be crueler than the punishment itself. To be certain, such an Eighth Amendment theory is unlikely to win acceptance. The idea that the government should be restrained by the possibility of illegal private retaliation is an open-ended principle which cannot easily be given effect and currently stands little chance of judicial acceptance. ${ }^{203}$ Similarly, although putting the individual to the choice of pleading guilty or seeing a spouse or child prosecuted could be said to implicate the cluster of constitutional values that surround the family unit, ${ }^{204}$ such a right again would be difficult to define substantively or implement realistically. Others have suggested that the Thirteenth Amendment should preclude the state from coercing the criminal defendant into becoming an undercover agent. ${ }^{205}$ Here again a "process value" argument seems narrower and more appealing. In all these cases, the "process value" approach provides a means of generating a penumbra around a substantive right that would not be afforded directly.

Accurate as the observation made by these critics appears to be, is it really a criticism? It seems less a vice and more a "passive

\footnotetext{
202 See Grey, Procedural Faimess and Substantive Rigbts, in XVII Nomos, note 197 supra, at 204-05 n.17.

${ }^{203}$ See Piemonte, 367 U.S. at 559 n.2.

204 For an overview of some of these constitutional values, see Burt, Tbe Constitution of the Family, 1979 SUPREME COURT REviEw 329.

${ }^{205}$ See Misner \& Clough, note 51 supra. Their analysis would not apply after conviction. Id. at 742-45.
} 
virtue" of this model that it can quietly achieve such results. Realistically, the premise that it is the principal function of due process to assure accurate fact finding seems too engrained with the current Court to expect more than marginal weight to be given to notions of "intrinsic" due process which fit awkwardly at best at sentencing. But exceptions to this generalization might be recognized chiefly when there is an overlap between the Dignitary Model's concerns and the penumbral reach of some undeveloped substantive constitutional right.

This brings me back to the Fifth Amendment. Its strongest proponents have always seen it as granting a "right to be left alone" or, at the least, as "designed to secure among governmental officials ... respect for the integrity and worth of the individual. . ."206 This value is eroded, however, when it becomes commonplace for prosecutors to apply extreme pressures routinely on minor figures in the hope that such pressure will produce essentially random information against major criminals. ${ }^{207}$ The intensity of the pressure, the state's disregard for the danger of reprisals to the informant, and the nonspecific character of the information sought by such dragnet techniques injure this value of the Fifth Amendment. Clearly, however, the current law is that once use immunity is granted, the concerns of that Amendment are deemed satisfied. But it is in this twilight zone that a linkage between Fifth Amendment values and a dignitary model for the Due Process Clause could be achieved. The tension in the law here has on occasion been recognized by the Court. ${ }^{208}$ Undoubtedly, the obligation to testify will remain, even in the face of danger, but it may be possible to demand of the state that it have a specific target or focus before it simply applies the screws to whatever defendants it has available.

Implementation of such a goal is, however, more problematic. In contrast to the earlier models which focus on truth distortion or the capacity for intelligent choice, it is coercion itself which this model finds offensive. As a result, it conflicts fundamentally with the basic institution of sentencing discretion. So long as there is a substantial

${ }^{208}$ See McKay, Self Incrimination and the New Privacy, 1967 Supreme Court Review 193, 209-10; see also Griswold, The Rigbt to Be Let Alone, 55 N.W.U.L. Rev. 216 (1961).

${ }^{207}$ See note 53 supra.

${ }^{208}$ In rejecting the argument that fear of a violent reprisal could excuse a refusal to testify, Justice Frankfurter still noted: "The Government, of course, has an obligation to protect its citizens from harm." Piemonte, 367 U.S. at 559 n.2. This obligation could conceivably deny government the ability to demand cooperation except where a specific target and independent corroboration existed. 
range of choice open to dispositional authorities, it is predictable that prosecutors and courts will utilize that discretion to achieve ends that are ulterior to any purely normative theory of punishment. After Grayson and Roberts, it would be extremely difficult for the Court to reject sentencing discretion because of its potential for coercive use.

Thus, the utility of a dignitary model may lie less in what it can reject and more in what it can affirmatively support. Legislative efforts to restrict sentencing discretion have been ubiquitous over the last five years. Eventually such efforts must make their separate peace with the institution of plea bargaining. To do so requires a candid balancing of the state's interest in offering concessions with the individual's interest in the effective exercise of his constitutional rights. This model, it will next be suggested, can help bridge this gap.

\section{The Model of Government Regularity: Toward SYNTHESIS AND IMPLEMENTATION}

What then are the theoretical perimeters, both existing and foreseeable, on the state's use of coercive pressure against the defendant to secure desired behavior? From a variety of perspectives, I have suggested that the much-discredited distinction of pluses versus minuses will be surprisingly sustainable if appropriate safeguards are observed. From a Fifth Amendment perspective, it seems comparatively simple to reward assistance without significantly penalizing the exercise of the privilege. The simplest and safest route to this end would be for the Court to reconsider its statement in Roberts that the privilege is not "self-executing" and recognize that what it really meant was that the judge could draw an adverse inference, not that the prosecutor could profit from the defendant's predicament and incriminate him so easily. If this interpretation of Roberts is correct, then several means to such a result are available. Whether by analogy to Baxter or to civil contempt sanctions, a sentencing differential can be rationalized. Such a difference should not exceed the civil contempt maximum penalty and should be given in the form of credit in order that the defendant who stands on his constitutional right not be treated differently than those for whom the matter never arises. Finally, because use immunity alone provides an illusory protection at sentencing, the 
Griffin rule should be extended to sentencing to preclude any communication to the court of the defendant's refusal to incriminate himself.

Once I turn from the Fifth Amendment to due process theories, few conclusions can be expressed with certainty. Nonetheless, the following limits seem likely:

1. Bordenkircher is unlikely to be stretched to reach postconviction threats since its logic rests heavily on the assumed equality of bargaining between the adversaries. Almost certainly it will not apply when a threat is made to indict a relative or spouse. In principle, the recognition that "false self-condemnation" can occur in these circumstances should lead to a similar result when the defendant has been denied bail and then is offered a plea under which prompt release is promised. Other situations are less clear, but certainly it is arguable that the defendant lacks the capacity for intelligent choice when the danger of a violent reprisal exists.

2. The still open question is whether the prosecutor may threaten the defendant in order to obtain testimonial cooperation. Although this undoubtedly happens on a daily basis, Bordenkircher's reach does not seemingly go this far, nor does Baxter authorize the use of any prosecutorial pressure. Even Trammel cannot fairly be said to legitimize such pressure, because the defendant there had been given use immunity. ${ }^{209}$ To understand this limited reach of Bordenkircher and Baxter, it is necessary to go back to their basic justification: each rationalizes a burden on a constitutional right by arguing that the ultimate outcome of the trial or hearing was not materially affected by such pressure. That is, since in the Court's view the factually innocent would not plead guilty (or would do so only if the odds on conviction were overwhelming), the pressure applied by the prosecutor is not truth distorting but merely expedites the eventual outcome to their mutual benefit. Similarly, since the adverse inference in Baxter was alone insufficient to support a finding against the prisoner, it also did not have a truth-distorting impact. However debatable the Court's logic may be, such an argument cannot reach a coerced waiver as to self-incriminating testimony. Here, but for the pressure, the waiver would be unlikely and the information so obtained will have an obviously material impact.

${ }^{209} 100$ S. Ct. at 914. 
Other distinctions are also apparent. The Fifth Amendment is intended to protect also the defendant who is factually guilty. The potential for truth distortion is then an irrelevant test to a constitutional protection which is as much concerned with protecting the defendant from having to incriminate himself as it is with the danger that coerced testimony may be unreliable.

Nonetheless, there is a possibility that one argument made in Bordenkircher will strike the Court as persuasive. In Bordenkircher, the Court observed that there is no point in developing a prophylactic rule if it still leaves the prosecutor the ability to charge the maximum penalty at the outset and then agree to a reduction if the defendant "voluntarily" approaches him with an offer to waive his right in return for leniency. ${ }^{210}$ Thus, the Court's willingness to reach a position of theoretical consistency may depend on the practical difficulties it sees in implementing such a rule.

3. The prophylactic rule here proposed can also be advanced under a Mathews rationale. Judicial involvement in securing cooperation by the defendant tends to raise significantly the risk of error and biased judgment. The state's interest is not comparable to the defendant's, given the availability of alternative sanctions (such as contempt penalties once use immunity is conferred). This balancing model, however, does not find sentencing credits for cooperation offensive since the possibility of bias is slight when the court is denied knowledge as to the defendant's noncooperation.

4. Blackledge, of course, establishes a procedural limit: the prosecutor may not retaliate vindictively but must give fair warning. Such a rule, however, does not restrict coercion; it only channels it. A far more important inhibition is the substantive one inherent in Menna v. New York's holding that some constitutional violations can be collaterally attached, notwithstanding a plea of guilty. ${ }^{211}$ The

\footnotetext{
210434 U.S. at 361 .
}

211423 U.S. 61 (1975). Menna says that a plea of guilty serves to establish factual guilt and therefore "renders irrelevant those constitutional violations not logically inconsistent with the valid establishment of factual guilt." Id. at $63 \mathrm{n} .2$. But when the defendant claims that "the State may not convict [him] no matter how validly his factual guilt is established," the guilty plea does not preclude a collateral attack. For example, the defendant could still claim that the statute was unconstitutional or that (as in Menna) the Double Jeopardy Clause precluded his prosecution. Menna, however, leaves open the possibility that even these claims might be waived: "We do not hold that a double jeopardy claim may never be waived. We simply hold that a plea of guilty to a charge does not waive a claim that-judged on its face-the charge is one which the State may not constitutionally prosecute." Ibid. Thus, the prosecutor would have to demand some formal waiver of the claim, rather than simply a plea of guilty, to 
class of constitutional violations so sheltered by Menna from the coercive pressure of both judge and prosecutor is uncertain, but the forgoing interpretation of Bordenkircher and Baxter as involving pressures that only expedited the outcome, but did not change it, merits consideration by the Court. Under such an analysis, pressure on the Fifth Amendment would fall on the illegitimate side of the line that separates Menna from Brady and Bordenkircher.

These then are the theoretical boundaries on the use of coercion by the prosecutor and judge. Obviously, they are transgressed daily. New developments - such as sentencing guidelines and a more formalized sentencing hearing-may substantially reduce the rate of judicial violation. In addition, the prophylactic rule here recommended which would cut the court off from information about the defendant's cooperation could be implemented so as to minimize this type of pressure. But the prosecutor still seems immune.

The basic problem here is that the Blackledge principle that precludes prosecutorial retaliation is incapable of adequate implementation. Such a principle is impotent if the prosecutor responds with an initial indictment on the maximum charge sustainable. The sophisticated prosecutor has only to refuse to bargain until the requisite cooperation is first offered by the defendant. In this light, Blackledge supplies a protection which works only in those contexts where the prosecutorial pressure cannot be pushed back to an earlier, more discretionary stage. Thus, Blackledge is relevant to a context such as that of prosecutorial appeals of the sentence, where if the prosecutor were precluded from retaliating against a defendant's appeal by a cross appeal, there would not be an earlier stage at which he could effectively chill the defendant from exercising a sentencing appeal. ${ }^{212}$ But elsewhere, Blackledge approaches being a hollow principle which, like Roberts, announces a high standard but

preelude collateral attack. Whether the Court would accept such a waiver in the coercive context of plea bargaining is unclear. Here the conflict between the doctrine of unconstitutional conditions and the Bordenkircber rationale has yet to be resolved, but the analysis in the above text suggests that the waiver should be rejected.

212 See commentary to ABA Standard 18-4.9 (recommending that where the prosecutor has the power to appeal the sentence it be confined to a shorter time span than that given the defendant). Cf. Walsh v. Picard, 446 F.2d 129 (1st Cir. 1971). It seems unlikely that the prosecutor would appeal every sentence in anticipation of a future appeal by the defendant. Other reforms are also possible: limit the prosecutor to appeals of sentences which are beneath the guideline range applicable to the offense and offender. 
then leaves the defendant who asserts his rights unprotected against the predictable retaliation.

What then can work to shelter the defendant from the prosecutor's ability to overcharge and then trade down? Here, we must leave theory behind and turn to the practical realities of implementation. Assuming that we deny the sentencing judge the ability to learn of the defendant's lack of cooperation, then the remaining problem is the prosecutor's ability to coerce the defendant through his charging discretion. To the degree we can shift the allocation of discretion from the prosecutor to the court and institutionalize the incentive to plea bargain or cooperate in the form of judicial sentencing guidelines, we take discretion out of the hands of the prosecutor. As a first step, we can limit this by extending Blackledge (and retracting Bordenkircher) so that reindictment following a refusal to cooperate would be viewed as an impermissible retaliation. But this still leaves the prosecutor the option of extending concessions only to those who cooperate. Although one may place some faint hope on prosecutorial guidelines and professional ethics to restrain the prosecutor, ${ }^{213}$ it is difficult to be optimistic about the overall efficacy of such high-minded reforms. Somehow, in order to make the judge the principal administrator of sentencing concessions, a capacity must be created within the criminal justice system to reverse or cancel out the concessions the prosecutor can now offer.

A new reform does offer considerable promise of creating this oversight capacity: "real offense sentencing." 14 Briefly, "real offense sentencing" means a sentencing or parole guidelines system which is based, not on the offense of conviction, but rather on the underlying "real" offense behavior. Sentences outside the guideline range would be subject to appellate review under a stricter standard of review and would require special justification by the court. Use of such a guideline system means that any charging concession the prosecutor grants can be cancelled out at either the sentencing or parole stage because the applicable guideline range used will ignore the prosecutor's charging concession. ${ }^{215}$ In effect, this makes the

${ }^{213}$ See Abrams, Internal Policy: Guiding tbe Exercise of Prosecutorial Discretion, 19 U.C.L.A. L. REv. 1 (1971); Note, Official Inducements to Plead Guilty: Suggested Morals for a Marketplace, 32 U. CHI. L. Rev. 167 (1964).

${ }^{214}$ For an overview, see commentary to ABA Standards, Section 18-3.1; see also Schulhofer, note 5 supra, at 757-72.

215 "Real offense" guidelines are in this sense a response to the critique, most articulately 
prosecutor's concession largely illusory and presumably has the impact of reducing his ability to plea bargain effectively. Precisely this logic has caused the Model Sentencing and Corrections Act to instruct the sentencing court to use the guideline range applicable to the "real offense" rather than the offense of conviction (to the extent that the real offense guideline range falls within the statutory ceiling for the offense of conviction). ${ }^{216} \mathrm{~A}$ similar approach has been used for some time by the United States Parole Commission and has withstood initial judicial scrutiny. ${ }^{217}$

"Real offense" sentencing then offers the most direct route to reducing prosecutorial pressure on the defendant. ${ }^{218}$ It comes, however, at a definite cost. First, critical determinations are being

voiced by Professor Alschuler, that the trend to determinate sentencing (whether fixed sentences or presumptive) simply reallocates authority from the court to the prosecutor. See Alschuler, Sentencing Reform and Prosecutorial Power: A Critique of Recent Proposals for Fixed and Presumptive Sentencing, 126 U. PA. L. REv. 550 (1978). Under a wholly indeterminate sentencing structure, the prosecutor only has a precatory impact on the sentence through his recommendations to the judge. But, if a "fixed" or "presumptive" sentencing structure cstablishes a definite sentence for each lesser included offense (e.g., five years for "robbery one," three years for "robbery two," and one year for attempted robbery), the prosecutor now controls the sentence through his charging discretion.

${ }^{216}$ N.C.C.U.S.L. Model Sentencing and Corrections Act, Section 3-206(d), reads: "In determining the appropriate guideline to follow, the court shall consider the nature and characteristics of the criminal conduct involved without regard to the offense charged. However, in the event that the guideline sentence is greater than the maximum sentence provided for the class of offense charged, the court may sentence the offender to no more than the maximum for the class of offense charged."

217 See Billiteri v. United States Board of Parole, 541 F.2d 938 (2d Cir. 1976); Bistram v. U.S. Parole Board, 535 F.2d 329 (5th Cir. 1976); Grattan v. Sigler, 525 F.2d 329 (9th Cir. 1975); Lupo v. Norton, 371 F. Supp. 156 (D. Conn. 1974). For a critical review of "real offense" sentencing guidelines, see Schulhofer, note 5 supra, at 757-72. Nonetheless, Professor Schulhofer concedes that "the constitutional problems posed by use of actualoffense behavior would not be insurmountable." Id. at 760. In principle, there seems no greater infringement of due process values by such a post-conviction reinterpretation of the offense than in judicial reliance at sentencing on aggravating facts unrelated to the crime and never alleged in court.

${ }^{218}$ No reform works perfectly, and it seems likely that evasions will develop in order to outflank "real offense" sentencing. In particular, what I bave elsewhere termed "fact bargaining" may arise to replace explicit plea bargaining as the parties seek to hide aggravating facts from the court's attention. See ABA Standards, Standard 18-3.1. In truth, this is already a well-established phenomenon, and courthouse regulars are well aware of the tendency for the defendant to "swallow his gun" if he pleads guilty. One factor can restrain this tendency: an adequately staffed probation office which gives its highest priority to the preparation of factual verified presentence reports.

Another difficult problem is how aggravating "real offense" facts will be proven at a more formalized sentencing hearing if the prosecution wishes to bargain them away in return for a plea of guilty or cooperation. Various answers are possible: (1) a specialized prosecution team for sentencing hearings, or (2) locating the "real offense" determination at the parole stage on the sound premise that a parole body has less of an institutional incentive to reward the cooperative defendant since, unlike the court or prosecutor, it is remote from the pressures of the docket and the caseload. See note 222 infra. 
pushed back from the trial stage to the sentencing stage where greater informality and potential for error adverse to the defendant prevails. ${ }^{219}$ For example, would one really be satisfied with a statutory structure under which the individual is convicted of a weapons charge but the "real offense" is determined at the sentencing hearing to have been homicide? Since Patterson v. New York, the constitutional dimensions of this problem have become particularly murky. ${ }^{220}$ In any event, the irony is evident: this approach to protecting the integrity of the trial stage from the corrosive effect of plea bargaining winds up similarly diminishing the significance of the constitutional rights the defendant enjoys at trial since critical issues are deferred to sentencing. Second, real offense sentencing, once successfully implemented at the sentencing stage, makes the benefits of plea bargaining largely illusory. ${ }^{221}$ In time, this is bound to have the effect of discouraging plea bargaining - a luxury most criminal justice systems cannot afford.

Thus, some compromise of real offense guidelines and plea bargaining appears necessary. The simplest route to this end is probably to incorporate in the guidelines system presumptive credits for pleading guilty or for providing significant cooperation. Such guidelines (which would probably work best at the parole stage) ${ }^{222}$

219 Some of this tendency to push critical facts back to the sentencing stage is already visible in the California statute. See Cal. Penal Code $\$ \S 1170.1$ (a) (c), 12022 and 667.5(d). For a critique, see Uelmen, Proof of Aggravation under the Califormia Uniform Determinate Sententing Act, 10 LoYola L. REv. 725 (1977).

220 This issue here involves the troubling and vague line of division between Mullaney v. Wilbur, 421 U.S. 684 (1975), which has language suggesting the proof "beyond a reasonable doubt" standard would be offended by the forgoing hypothetical statute, and Patterson v. New York, 432 U.S. 197 (1977), which suggests otherwise. See also Note, The Constitutionality of Statutes Permitting Increased Sentences for Habitual or Dangerous Criminals, 89 HARv. L. REv. 356 (1975), and commentary to Section 3-207 of the Model Sentencing and Corrections Act.

${ }^{221}$ For example, if the offender is potentially facing a twenty-year maximum sentence and negotiates a bargain with the prosecutor under which the prosecutor will recommend that the sentence not exceed seven years, this bargain is of little practical value if the guideline range recommends three to five years. Hence, the defendant has little incentive to plead under a "real offense" guideline system.

${ }^{222}$ It is noteworthy that "real offense" guidelines are today employed by the United States Parole Commission, an agency which is organizationally removed from the pressures which lead courts to accept plea bargaining. Whether courts will be long willing to observe such guidelines may in effect become a question of whether they can live with a substantial reduction in plea bargaining. Alternatively, what may happen is that a new form of plea bargaining will appear as defense counsel seek a discount from the guideline range. If one is interested in the goal of sentencing equality, this supplies a powerful argument for the retention of a parole agency. See ABA Standard 18-4.1. 
might establish, for example, a presumptive term of three to five years for a given combination of offense and offender characteristics and also provide for a credit of one year for a plea of guilty and a credit of six to eighteen months in cases where the defendant provided significant assistance to law enforcement authorities. ${ }^{223}$ Corbitt probably permits such pressure to plead guilty since the credit is only presumptive and not mandatory. ${ }^{224}$

To many, such explicit credits for the waiver of constitutional rights will be deemed scandalous. But they may have fallen prey to the "All-Good-Things-Go-Together Fallacy." 225 The cost of more idealistic remedies is often that they are ineffective. No statement would be easier for the Court to make in the next post-Roberts case it hears than that the sentencing judge should not retaliate. But such rhetoric is not a remedy, and, in a system not willing to abolish plea bargaining, coercion is inescapable. Even if it can be denied to the court, it will remain in the hardly more accountable hands of the prosecutor. It seems wiser to seek to structure and confine the use of coercion than to attempt to abolish it. Once coercion is legitimized and brought out into the open, it can be tamed and mitigated in its intensity. The goal of sentencing equality is probably injured less by explicit deviations in the form of credits for a plea than it is by invisible decisions now made at the charging and plea-bargaining stages.

Better then a system in which all defendants are entitled to a modest concession for a plea of guilty or other desired behavior than a system in which a few defendants may be subjected to intense pressures. Few foxes could be more dangerously released within the criminal justice system's henhouse than a strict interpretation of the doctrine of unconstitutional conditions. Discretion would still remain somewhere within the system and would be exercised severely against some. In contrast, sentencing concessions may be doctrinally impure, but, if they do constitute a threat, such threats are eminently resistible and hold little likelihood of truth

${ }^{223}$ I assume here that greater breadth is needed in the cooperation guideline since it deals with more variable phenomena, involving a wide continuum of assistance and risk.

224 Corbitt would seem squarely on point if the two guideline ranges overlapped: that is, a guideline range of two to three years for the noncooperating defendant and one to two for the cooperating defendant. See Schulhofer, note 5 supra, at 771-83.

${ }^{225}$ This term was apparently coined by Gordon Tullock. See Tullock, Does Punisbment Deter Crime? 36 PubliC INTEREST 103, 109 (1974). 
distortion. The defendant who has a 40 percent chance of acquittal will not surrender that chance for a six-month concession, as he might under a system which threatens him with a life sentence.

It might be argued that the state can no more be a little bit coercive than one can be a little pregnant. In time, such a critic would say, coercion, once legitimized, would grow until defendants are compelled to waive their rights. A partial reply to this argument might be to inquire whether defendants are not already so threatened today. But the more important response to this claim is that it ignores the dynamics of public accountability. It is difficult to conceive of a state sentencing commission authorizing the kind of five-year credit for a plea of guilty that prosecutors regularly give defendants today. ${ }^{26}$ Such a public body with a system-wide perspective can better resist the ad hoc pressures that lead the prosecutor to use often egregious levels of pressure. The best remedy for plea bargaining is not to slay the dragon but to tame it.

The corpse of the rehabilitative model will eventually be interred by the Supreme Court. The long-term issues concern what is to replace it. I recommend an impure model-the Model of Government Regularity. Under such a model, the state need not always refrain from inducing or even threatening, but it must act in an even-handed way and must apply only limited pressures. Guidelines would publicly express the discount off the presumptive term that might be earned, but no enhancement of the term would be permitted because of the exercise of constitutional rights. Ultimately, such limited powers are less to be feared than noble promises and empty remedies.

For those who find arguments premised on the behavior of the rational defendant or prosecutor unpersuasive, the folk wisdom inherent in an old Abbott and Costello routine may best illustrate my thesis: Charged with a minor offense, Costello wanted to "pay the $\$ 2.00$," but Abbott as his idealistic lawyer insisted that he fight the case to the highest court in the land. Steadily, the stakes mount, and in the last scene, Costello is on Death Row, still protesting to

${ }^{226}$ In Corbitt, Mr. Justice Stewart suggests that it is more defensible for an adversary (i.e., the prosecutor) to give a concession for the plea of guilty than for the legislature. 439 U.S. at 227 . From a policy perspective, this is egregiously wrong, since the likelihood of ad boc pressures, personal vendettas, or simply disparities among prosecutors is removed when the credit is centrally established.

With respect to the concessions currently granted for a plea of guilty, see note 48 supra. 
Abbott that he only wanted to pay the $\$ 2.00$. This joke was funnier before Mr. Hayes's failed attempt to contest a $\$ 88.30$ bad check charge resulted in a life sentence. In the last analysis, those unwilling to see the institutionalization of guideline credits appear to be taking the side of Abbott and forcing defendant Costello to fight a losing battle. ${ }^{227}$

${ }^{227}$ This conclusion rests, not simply on my belief that plea bargaining will remain a feature of urban courtrooms for some time to come, but even more on my belief that, if it were abolished, the legislature would not respond by reducing the severity of the penalty structure. Harsh sentences are politically popular. From this premise, the policy impact of plea bargaining, even as authorized by Bordenkircber, is to increase the number of defendants who plead guilty and at the same time to moderate the severity of the punishment assigned them. Institutional features, such as prison overcrowding and limited resources, combine to make this cost-spreading impact virtually inevitable.

But as we reduce the maximum level of pressure that can be placed on the defendant to plead guilty or cooperate by offering only moderate sentencing concessions (instead of the huge disparity in Bordenkircber), some desirable changes follow: (1) Risk aversion becomes less of a factor and its impact is always erratic. (2) Only those whose likelihood of conviction is high are likely to be induced to plead gnilty by modest concessions. Thus, Bordenkircber's premise that "false self-condemnation" is unlikely should become true, if we place a substantially lower ceiling on the level of pressure that can be brought to bear. 